\title{
Modeling of sulfur gases and chemiions in aircraft engines
}

\section{Modellierung von schwefelhaltigen Gasen und Chemi-Ionen in Flugzeug-Triebwerken}

\author{
Alexander M. Starik ${ }^{\mathrm{a}}$, Alexander M. Savel'ev ${ }^{\mathrm{a}}$, Natalia S. Titova ${ }^{\mathrm{a}}$, Ulrich Schumann ${ }^{\mathrm{b}, *}$ \\ ${ }^{a}$ Central Institute of Aviation Motors, Scientific Research Center "Raduga", 111250 Moscow, Russia \\ ${ }^{\mathrm{b}}$ Deutsches Zentrum für Luft- und Raumfahrt (DLR), Institute of Atmospheric Physics, Oberpfaffenhofen, 82230 Wessling, Germany
}

Received 17 August 2001; received in revised form 17 January 2002; accepted 17 January 2002

\begin{abstract}
The formation of sulfur-containing gases and chemiions in the combustor and their evolution in the turbine of aircraft-engines between combustor exit and engine exit are computed including the conversion fraction of fuel sulfur into $\mathrm{SO}_{3}$ and $\mathrm{H}_{2} \mathrm{SO}_{4}$. The combustion is approximated by an adiabatic time-dependent box-model. The temperature and pressure evolution in the flow between combustor exit and engine exit is modeled using a quasi one-dimensional (Q1D) model. New kinetic models for S-containing gases and chemiions are used. About $1 \%$ of the sulfur molecules are computed to be converted into $\mathrm{SO}_{3}$ within the combustor and about $10 \%$ into $\mathrm{SO}_{3}$ and $\mathrm{H}_{2} \mathrm{SO}_{4}$ before engine exit. Box models agree with the Q1D results for the same initial and thermodynamic conditions, but underestimate sulfur conversion by a factor of 3 if using a linear temperature profile. The number of positive and negative ions formed within the combustor, mainly $\mathrm{NO}^{+}$ and $\mathrm{HSO}_{4}^{-}$, depends strongly on the fuel/air ratio and on recombination reactions, mainly with $\mathrm{C}_{2} \mathrm{H}_{3} \mathrm{O}^{+}$ions. The model computes a total ion emission of $2 \cdot 10^{15}$ per $\mathrm{kg}$ of fuel burned at cruise. Far larger ion concentrations close to values observed behind engines at ground, are computed for higher combustor inlet pressure and higher fuel/air ratio. @ 2002 Éditions scientifiques et médicales Elsevier SAS. All rights reserved.
\end{abstract}

\section{Zusammenfassung}

Die Bildung von schwefelhaltigen Gasen und Chemi-Ionen in der Brennkammer von Flugzeugtriebwerken und ihre Veränderung in der Turbine zwischen Brennkammer und Treibwerksaustritt werden berechnet, einschließlich der Umwandlung von Treibstoff-Schwefel in $\mathrm{SO}_{3}$ und $\mathrm{H}_{2} \mathrm{SO}_{4}$. Die Verbrennung wird mit einem adiabatischen instationären Box-Modell approximiert. Das Temperatur- und Druck-Profil entlang der Strömung vom Brennkammer-Austritt bis Triebwerks-Austritt werden mit einem quasi-eindimensionalen (Q1D) StrömungsModel berechnet. Für die Kinetik der S-haltigen Gase und der Chemi-Ionen werden neue Modelle benutzt. Etwa 1\% der Schwefelmoleküle werden in der Brennkammer in $\mathrm{SO}_{3}$ und etwa $10 \%$ in der Turbine in $\mathrm{SO}_{3}$ und $\mathrm{H}_{2} \mathrm{SO}_{4}$ umgewandelt. Für gleiche thermodynamische Bedingungen liefern Box-Modelle gleiche Ergebnisse, unterschätzen aber die Umwandlung um einen Faktor 3, wenn das Temperaturprofil in der Turbine durch ein lineares Profil approximiert wird. Die Zahl der positiven and negativen Ionen, die in der Brennkammer gebildet werden, vorwiegend $\mathrm{NO}^{+}$and $\mathrm{HSO}_{4}^{-}$, hängt stark vom Treibstoff/Luft-Verhältnis und den Rekombinations-Reaktionen, vorwiegend mit $\mathrm{C}_{2} \mathrm{H}_{3} \mathrm{O}^{+}$ Ionen, ab. Im Modell werden insgesamt $2 \cdot 10^{15}$ Ionen pro kg verbrannten Treibstoffs unter Reiseflugbedingengen emittiert. Sehr viel größere Konzentrationen, wie am Boden hinter Triebwerken gemessen, werden für höhere Brennkammerdrücke und Brennstoff/Luft-Verhältnisse berechnet. ㅇ 2002 Éditions scientifiques et médicales Elsevier SAS. All rights reserved.

Keywords: Combustion; Jet engine; Chemiion; Sulfur; Model

Schlüsselwörter: Verbrennung; Strahl-Triebwerk; Chemi-Ionen; Schwefel; Model

\section{Introduction}

\footnotetext{
* Corresponding author.

E-mail address: ulrich.schumann@dlr.de (U. Schumann).
}

Aerosols forming in the exhaust plume of aircraft engines may significantly perturb the chemical and physical 
processes in the atmosphere [7,27]. Most of the particles forming in exhaust plumes behind aircraft at cruise are liquid and contain sulfuric acid [13,45,50,53], and some condensable hydrocarbons $[28,53]$. The formation of volatile aerosols in aircraft plumes depends on the amounts of gaseous $\mathrm{O}, \mathrm{OH}, \mathrm{SO}_{2}, \mathrm{SO}_{3}$, and $\mathrm{H}_{2} \mathrm{SO}_{4}$, and on chemiions (CIs) emitted from the engines [22,61]. Sulfur dioxide is the main product of oxidation of fuel sulfur during burning of aviation kerosene in gas turbine engine combustors [8]. The concentrations of $\mathrm{OH}, \mathrm{SO}_{3}$, and $\mathrm{H}_{2} \mathrm{SO}_{4}$ at core engine exit depend on the non-equilibrium chemistry in the combustor and on reactions of the exhaust gases in the postcombustor flow from the combustor through the turbine and the expansion nozzle to the engine exit $[9,36,46]$.

The fraction $\varepsilon$ of conversion of $\mathrm{SO}_{2}$ to $\mathrm{SO}_{3}$ and $\mathrm{H}_{2} \mathrm{SO}_{4}$ is defined in terms of respective mole fractions as $\varepsilon=\left(\left[\mathrm{SO}_{3}\right]+\left[\mathrm{H}_{2} \mathrm{SO}_{4}\right]\right) /\left[\mathrm{SO}_{x}\right]$, where $\mathrm{SO}_{x}$ includes all sulfur containing molecules resulting from fuel combustion. For homogeneous nucleation, the nucleation rate and the number density of volatile sulfate aerosol particles depends strongly on the magnitude of $\varepsilon$. If the volatile particles nucleate mainly on CIs, then $\varepsilon$ controls the size of volatile particles formed [29].

The conversion fraction $\varepsilon$ has been the topic of several studies [53]. Values of $\varepsilon$ larger than $12-45 \%$ and $6-31 \%$ have been deduced from measurements of aerosols and $\mathrm{CO}_{2}$ concentration behind a Concorde and a B-757 aircraft, respectively $[18,38]$. Direct measurements of sulfuric acid in the exhaust plume imply far smaller values of the sulfur conversion fraction $\varepsilon$ of $\sim 1.2 \%$ [2], $>0.4 \%$ [13], or $3.3 \% \pm 1.8 \%$ [14]. Modeling studies assuming equilibrium conditions at combustor exit and taking into account the oxidation of $\mathrm{SO}_{2}$ with $\mathrm{OH}$ and $\mathrm{O}$ radicals inside the engine between combustor and engine exit show that $\varepsilon$ may reach values up to about $10 \%[8,36,46,58]$. These calculations suffer from large uncertainties on the amount of $\mathrm{SO}_{3}, \mathrm{OH}$, $\mathrm{O}$, and other gases formed within the combustor.

Another important precursor of volatile particles formed in aircraft engine exhaust are CIs $[23,28,53,61,62]$. Plume aerosol models require information on the type and concentration of ions reaching the nozzle exit. The ion formation inside an aircraft engine has not yet been modeled. Recent measurements in the exhaust of jet engines revealed negative ions with $\mathrm{HSO}_{4}^{-}$cores, $\mathrm{NO}_{3}^{-}$cores and ions containing $\mathrm{C}, \mathrm{H}$ and $\mathrm{O}$ atoms [2,32] and positive ions including massive hydrocarbons [33]. The number density of ions at engine exit is still quite uncertain. For modeling nucleation consistent with volatile particle observations, engine exit CI number densities as large as $10^{9} \mathrm{~cm}^{-3}$ have been assumed [61]. Such large CI concentrations were observed for a premixed rich acetylene-oxygen flame at a fuel/air equivalence ratio $\phi$ of $1.5-3$ and an initial pressure of $\sim 20$ torr $[10,31]$ and in rich $(\phi=2.13)$ and lean $(\phi=0.2)$ premixed methane-oxygen flames at 40 torr [24] and 760 torr [43]. Maximum ion concentrations measured in such flames are $\left[\mathrm{H}_{3} \mathrm{O}^{+}\right]=1.5 \cdot 10^{11}$ $\mathrm{cm}^{-3}$ and $\left[\mathrm{C}_{2} \mathrm{H}_{3} \mathrm{O}^{+}\right]=10^{10} \mathrm{~cm}^{-3}$. But these flame condi- tions differ significantly from conditions in engine combustors which burn aviation kerosene with air under lean conditions $(\phi=0.25-0.33)$, at higher pressure $P_{0} \approx 1 \mathrm{MPa}$, higher temperature, and at shorter time scales (a few milliseconds). Moreover, the fuel/air ratio varies in a complex manner from rich to lean within the combustor. Only a few studies investigated the emission of CIs from aircraft engines. A total negative ion concentration of $1.4 \cdot 10^{7} \mathrm{~cm}^{-3}$ was measured at plume ages of about $10 \mathrm{~ms}$ after engine exit at ground [2]. Negative ions observed inside the plume of an Airbus A310 aircraft cruising at $10.4 \mathrm{~km}$ altitude at plume ages of about $2 \mathrm{~s}$ were found to be mainly $\mathrm{HSO}_{4}^{-}\left(\mathrm{H}_{2} \mathrm{SO}_{4}\right)_{m}$, $\mathrm{HSO}_{4}^{-}\left(\mathrm{HNO}_{3}\right)_{m}$, and $\mathrm{NO}_{3}^{-}\left(\mathrm{HNO}_{3}\right)_{m}$ ions [3]. The upper limit concentrations of negative and positive ions estimated from the measurements was $3 \cdot 10^{5}-3 \cdot 10^{6} \mathrm{~cm}^{-3}$ for these conditions. Dilution [51] implies about 300 times larger concentrations at engine exit, and larger values to account for recombination processes. A total positive CI concentration of $1.6 \cdot 10^{8} \mathrm{~cm}^{-3}$ was measured in the exhaust of a jet engine at ground at $12 \mathrm{~ms}$ plume age [4]. The local number concentration $c$ of ions per unit volume is related to an ion emission index EI (number of ions per unit mass of fuel burned) by $c=\operatorname{EI} \rho / N$, where $\rho$ is the local plume gas density for given temperature and pressure, and $N$ is the dilution factor (mass of air mixed with the exhaust from a unit mass of fuel burned [51]; for $16 \%$ hydrogen content in the fuel, the dilution factor in the engine is related to the equivalence fuel/air ratio $\phi$ by $N=16.2 / \phi$ ). Some models require an initial total ion concentration of the sum of positive and negative ions at engine exit of $4 \cdot 10^{8} \mathrm{~cm}^{-3}$ at temperature $T=600 \mathrm{~K}$ and pressure $P=220 \mathrm{hPa}$, or an ion emission index of $2 \cdot 10^{17}$ per $\mathrm{kg}$ of fuel burned [28,29,62]. For emission indices far larger than these values coagulation and recombination processes would quickly reduce the effective emission indices [61].

The dependence of ion emissions on the combustion process and the processes within the engine have not yet been determined. Therefore this paper investigates the formation of aerosol precursors in the combustor and the influence of various fluid dynamic and chemical kinetic processes within the gas turbine engine on the levels of sulfate aerosol precursors and CIs at engine exit.

\section{Kinetic model}

The formation of sulfur containing species $\left(\mathrm{SO}_{x}, \mathrm{HSO}_{3}\right.$, $\mathrm{H}_{2} \mathrm{SO}_{4}$ ) and CIs within the combustor and in the engine, in the core flow from the combustor through the gas turbine and the nozzle, is simulated with a new kinetic scheme. The scheme involves more than 1000 reversible reactions with participation of 117 neutral gas species: $\mathrm{H}_{z}, \mathrm{~N}_{z}(z=1,2)$, $\mathrm{O}_{x}(x=1, \ldots, 3), \mathrm{HO}_{x}, \mathrm{H}_{2} \mathrm{O}_{z}, \mathrm{NO}_{x}, \mathrm{HNO}_{y}(y=1, \ldots, 4)$, $\mathrm{N}_{z} \mathrm{H}_{y}, \mathrm{C}_{z}, \mathrm{C}_{m} \mathrm{H}_{n}(m=1, \ldots, 8, n=1, \ldots, 18), \mathrm{CO}_{z}, \mathrm{HCN}$, $\mathrm{C}_{m-1} \mathrm{H}_{n-1} \mathrm{O}_{z}, \mathrm{~S}_{z}, \mathrm{SO}_{x}, \mathrm{HSO}_{x}, \mathrm{H}_{2} \mathrm{SO}_{4}, \mathrm{COS}, \mathrm{H}_{2} \mathrm{~S}, \mathrm{CS}_{2}$ and 35 negative $\left(\mathrm{H}^{-}, \mathrm{OH}^{-}, \mathrm{O}^{-}, \mathrm{O}_{2}^{-}, \mathrm{O}_{3}^{-}, \mathrm{O}_{4}^{-}, \mathrm{CO}_{3}^{-}, \mathrm{CO}_{4}^{-}\right.$, $\left.\mathrm{CN}^{-}, \mathrm{NO}^{-}, \mathrm{NO}_{2}^{-}, \mathrm{NO}_{3}^{-}, \mathrm{SO}_{2}^{-}, \mathrm{SO}_{3}^{-}, \mathrm{SO}_{4}^{-}, \mathrm{HSO}_{4}^{-}\right)$and 
positive $\left(\mathrm{CHO}^{+}, \mathrm{CH}_{3}^{+}, \mathrm{C}_{2} \mathrm{H}_{3}^{+}, \mathrm{C}_{3} \mathrm{H}_{3}^{+}, \mathrm{CH}_{2} \mathrm{OH}^{+}, \mathrm{C}_{2} \mathrm{H}_{3} \mathrm{O}^{+}\right.$, $\mathrm{C}^{+}, \mathrm{CO}^{+}, \mathrm{CO}_{2}^{+}, \mathrm{H}_{3} \mathrm{O}^{+}, \mathrm{H}_{2} \mathrm{O}^{+}, \mathrm{O}^{+}, \mathrm{O}_{2}^{+}, \mathrm{N}^{+}, \mathrm{N}_{2}^{+}, \mathrm{NO}^{+}$, $\mathrm{NO}_{2}^{+}, \mathrm{NH}_{3}^{+}, \mathrm{NH}_{4}^{+}$) ions. The kinetic model is based on our previous investigations of gaseous combustion kinetics for hydrocarbons-air mixtures $[15,56,57]$. The gas phase model for $\mathrm{NO}_{x}, \mathrm{HO}_{x}$ and $\mathrm{SO}_{x}$ chemistry is close to a previously developed model [46]. The model was previously applied for an aircraft engine duct with prescribed initial conditions at combustor exit based on equilibrium calculations. The main reaction paths for $\mathrm{NO}_{x}, \mathrm{HNO}_{y}, \mathrm{HO}_{x}, \mathrm{SO}_{x}$, and $\mathrm{HSO}_{y}$ gases inside the mid-pressure turbine section were analyzed from that study. For the present study, the model has been extended to incorporate a more detailed S-containing species chemistry and a new ion-chemistry model. The reactions of $\mathrm{SO}_{x}-\mathrm{S}-, \mathrm{H}_{x} \mathrm{~S}-, \mathrm{HSO}_{y}$ - and $\mathrm{CS}_{x}$-species included in the chemical model used in this paper are listed in the appendix, Table A1. All reactions are considered reversible. The rate constants of the backward reactions are determined from calculated equilibrium constants [46]. Large uncertainties exist in the sulfur chemistry, mainly because of missing data on reactions of $\mathrm{SO}_{2}$ with $\mathrm{OH}$ at the high temperatures in the combustor and high pressure turbine [58]. The present study cannot contribute new information in this respect. For the formation of $\mathrm{H}_{2} \mathrm{SO}_{4}$ from $\mathrm{SO}_{3}$ and $\mathrm{H}_{2} \mathrm{O}$ [45] we note that the model uses a temperature independent summary reaction as suggested earlier $[9,36]$.

The types of reactions for ion chemistry included in this kinetic model are listed in Table 1. The full set of ion reactions includes more than 400 reactions as listed in the appendix, Table A2. The block of ion chemistry is devel- oped from measured ion kinetics during combustion [10, $11,17,41]$, shock waves in air [40], plasmochemical kinetics in electric discharge $[35,42,55]$, and in the atmosphere [5,19-21,30,54]. Most of the rate constants for ion chemistry were determined only for low temperature ranges (300$500 \mathrm{~K}$ ). For the far higher temperatures in the combustor and postcombustor flows, extrapolations are used in accordance with theory for the various types of reactions. For backward reactions for which the Arrhenius dependency is not listed in Table A2, the rate constants are determined using calculated equilibrium constants. The model does not include interactions with heavy hydrocarbon ions $\left(\mathrm{C}_{5} \mathrm{H}_{3}^{+}\right.$, $\mathrm{C}_{7} \mathrm{H}_{5}^{+}, \mathrm{C}_{13} \mathrm{H}_{9}^{+}$, etc.) which are expected to be of small importance for lean engine combustion conditions. Many of the ion-ion and ion-neutral species reactions are known only with considerable uncertainty as discussed in the references cited. Nevertheless, the results computed with this kinetic scheme show a good correlation with experimental data on ignition delay in mixtures of hydrocarbons with air [56] and on $\mathrm{CHO}^{+}, \mathrm{C}_{2} \mathrm{H}_{3} \mathrm{O}^{+}, \mathrm{H}_{3} \mathrm{O}^{+}, \mathrm{C}_{3} \mathrm{H}_{3}^{+}$ion concentrations in $\mathrm{CH}_{4}$ /air flames [41].

\section{Chemiion formation during combustion}

Aviation kerosene is a mixture of high-order hydrocarbons and contains $0.0001 \%$ to $0.3 \%$ sulfur per mass, with median values near $0.04 \%$. Sulfur is contained in aromatic and polyaromatic groups of high-order hydrocarbons in the fuel. The fuel/air mixture enters the combustor of a mod-

Table 1

Reactions mechanism for chemiions formation

\begin{tabular}{|c|c|c|}
\hline Type of reaction & Symbols & Reaction products \\
\hline 1. Reaction with $\mathrm{CH}, \mathrm{CH}\left(a^{4} \Sigma^{-}\right)$ & $\begin{array}{l}\mathrm{CH}\left(\mathrm{CH}^{*}\right)+\mathrm{O}=\mathrm{HCO}^{+}+\mathrm{e}^{-} \mathrm{CH}^{*} \\
+\mathrm{C}_{2} \mathrm{H}_{2}=\mathrm{C}_{3} \mathrm{H}_{3}^{+}+\mathrm{e}^{-}\end{array}$ & $\mathrm{HCO}^{+}, \mathrm{C}_{3} \mathrm{H}_{3}^{+}, \mathrm{e}^{-}$ \\
\hline 2. Associative ionization & $\mathrm{A}+\mathrm{B}=\mathrm{AB}^{+}+\mathrm{e}^{-}$ & $\mathrm{N}_{2}^{+}, \mathrm{O}_{2}^{+}, \mathrm{NO}^{+}, \mathrm{C}_{3} \mathrm{H}_{3}^{+}, \mathrm{e}^{-}$ \\
\hline 3. Dissociative ionization & $\mathrm{AB}+\mathrm{e}^{-}=\mathrm{A}^{-}+\mathrm{B}$ & $\mathrm{O}^{-}, \mathrm{O}_{2}^{-}, \mathrm{NO}_{2}^{-}$ \\
\hline 4. Ionization under molecule and electron interaction & $\mathrm{AB}+\mathrm{e}^{-}=\mathrm{AB}^{+}+2 \mathrm{e}^{-}$ & $\mathrm{O}_{2}^{+}, \mathrm{N}_{2}^{+}, \mathrm{NO}^{+}, \mathrm{O}^{+}, \mathrm{N}^{+}$ \\
\hline 5. Associative electron attachment & $\mathrm{AB}+\mathrm{e}^{-}=\mathrm{AB}^{-}$ & $\mathrm{O}^{-}, \mathrm{O}_{2}^{-}, \mathrm{NO}^{-}, \mathrm{NO}_{2}^{-}$ \\
\hline \multirow{3}{*}{ 7. Binary ion-molecular reactions } & $\mathrm{A}^{-}+\mathrm{B}=\mathrm{A}+\mathrm{B}^{-}$ & $\mathrm{NO}_{2}^{-}, \mathrm{NO}_{3}^{-}, \mathrm{O}^{-}, \mathrm{O}_{2}^{-}, \mathrm{O}_{3}^{-}, \mathrm{H}^{-}, \mathrm{OH}^{-}, \mathrm{SO}_{2}^{-}$ \\
\hline & $\mathrm{A}^{+}+\mathrm{BC}=\mathrm{B}+\mathrm{AC}^{+}$ & $\begin{array}{l}\mathrm{HCO}^{+}, \mathrm{H}_{3} \mathrm{O}^{+}, \mathrm{CH}_{2} \mathrm{OH}^{+}, \mathrm{H}_{2} \mathrm{O}^{+}, \mathrm{CH}_{3}^{+}, \mathrm{C}_{2} \mathrm{H}_{3} \mathrm{O}^{+}, \\
\mathrm{C}_{2} \mathrm{H}_{3}^{+}, \mathrm{C}_{3} \mathrm{H}_{3}^{+}, \mathrm{C}^{+}, \mathrm{N}_{2}^{+}, \mathrm{N}^{+}, \mathrm{NO}^{+}, \mathrm{NO}_{2}^{+}, \mathrm{NH}_{3}^{+}, \\
\mathrm{NH}_{4}^{+}, \mathrm{O}^{+}, \mathrm{O}_{2}^{+}, \mathrm{CO}^{+}\end{array}$ \\
\hline & $\mathrm{A}^{-}+\mathrm{BC}=\mathrm{B}+\mathrm{AC}^{-}$ & $\begin{array}{l}\mathrm{NO}^{-}, \mathrm{NO}_{2}^{-}, \mathrm{NO}_{3}^{-}, \mathrm{O}^{-}, \mathrm{O}_{2}^{-}, \mathrm{O}_{3}^{-}, \mathrm{O}_{4}^{-}, \mathrm{OH}^{-}, \mathrm{CN}^{-}, \\
\mathrm{CO}_{3}^{-}, \mathrm{CO}_{4}^{-}, \mathrm{SO}_{2}^{-}, \mathrm{SO}_{3}^{-}, \mathrm{SO}_{4}^{-}, \mathrm{HSO}_{4}^{-}\end{array}$ \\
\hline 10. Dissociative recombination & $\begin{array}{l}\mathrm{A}^{-}+\mathrm{B}+\mathrm{M}=\mathrm{AB}^{-}+\mathrm{M} \\
\mathrm{AB}^{+}+\mathrm{e}^{-}=\mathrm{A}+\mathrm{B}\end{array}$ & $\begin{array}{l}\mathrm{NO}_{2}^{-}, \mathrm{O}_{3}^{-}, \mathrm{CO}_{3}^{-}, \mathrm{O}_{4}^{-}, \mathrm{O}^{-}, \mathrm{CO}_{4}^{-} \\
\text {Neutral }\end{array}$ \\
\hline 11. Ion-electron recombination & $\mathrm{AB}^{+}+\mathrm{e}^{-}=\mathrm{AB}$ & Neutral \\
\hline 12. Binary ion-ion recombination & $\mathrm{AB}^{-}+\mathrm{C}^{+}=\mathrm{AB}+\mathrm{C}$ & Neutral \\
\hline 13. Ternary ion-ion recombination & $\mathrm{AB}^{-}+\mathrm{C}^{+}+\mathrm{M}=\mathrm{AB}+\mathrm{C}+\mathrm{M}$ & Neutral \\
\hline
\end{tabular}


ern gas turbine engine typically with initial temperature $T_{0}=1000 \mathrm{~K}$ and pressure $P_{0}=1 \mathrm{MPa}$. After thermal destruction of these hydrocarbons in the combustor, lighter hydrocarbons form and the sulfur contained in the hydrocarbon fuel is transformed into $\mathrm{H}_{2} \mathrm{~S}$. Our model assumes an initial mixture containing $n-\mathrm{C}_{8} \mathrm{H}_{18}$ thermal destruction products ( $16 \%$ hydrogen mass fraction) mixed with air and $\mathrm{H}_{2} \mathrm{~S}$ at an equivalence fuel/air ratio $\phi=0.25$ (dilution factor $N=64.7)$.

The ignition and combustion process in the combustor is simulated by integrating the kinetic equations versus time assuming a homogenous mixture in an adiabatically closed reactor from a time before ignition until an exit time $\tau_{\text {exit }}$. The value of $\tau_{\text {exit }}$ is selected such that the computed emission index of $\mathrm{NO}_{x}$ is in agreement with the $\mathrm{NO}_{x}$ emission index of an $R B 211$ engine of type $R B 211-524 B$ measured on an altitude test chamber [49]. We use $\tau_{\text {exit }}=1 \mathrm{~s}$ for cruise conditions with $T_{0}=1000 \mathrm{~K}, P_{0}=1 \mathrm{MPa}, \phi=0.25$, and $\tau_{\text {exit }}=10^{-2} \mathrm{~s}$ for ground conditions with $T_{0}=1250 \mathrm{~K}$, $P_{0}=4.5 \mathrm{MPa}, \phi=0.33$ or 0.25 . For cruise conditions, Fig. 1 depicts the temporal evolution of the computed mixing ratios of $\mathrm{N}-(\mathrm{a})$, and S-containing (b) species, and CIs (c) during combustion of $\mathrm{C}_{8} \mathrm{H}_{18}$ thermal destruction products mixed with air and $\mathrm{H}_{2} \mathrm{~S}$ for a typical fuel sulfur content (FSC) of $0.04 \%$. Ignition occurs at $t \sim 10^{-2} \mathrm{~s}$. After ignition the combustion products contain relatively large amounts of $\mathrm{SO}_{2}$, some $\mathrm{SO}_{3}$, and smaller amounts of $\mathrm{HSO}_{3}$ and $\mathrm{H}_{2} \mathrm{SO}_{4}$, and trace amounts of $\mathrm{C}_{2} \mathrm{H}_{3} \mathrm{O}^{+}, \mathrm{NO}^{+}, \mathrm{H}_{3} \mathrm{O}^{+}, \mathrm{HSO}_{4}^{-}, \mathrm{SO}_{3}^{-}$, and $\mathrm{NO}_{3}^{-}$ions. Some species such as $\mathrm{HSO}$ and $\mathrm{SO}_{3}^{-}$get formed temporarily during ignition and disappear when the reactions continue for more than $0.1 \mathrm{~s}$ in the closed reactor in these simulations. The gas species $\mathrm{SO}_{3}, \mathrm{HSO}_{3}, \mathrm{H}_{2} \mathrm{SO}_{4}$, $\mathrm{NO}, \mathrm{NO}_{2}, \mathrm{NO}_{3}, \mathrm{HNO}_{2}, \mathrm{HNO}_{3}, \mathrm{OH}, \mathrm{HO}_{2}, \mathrm{O}$, and the CIs at the combustor exit do not reach local chemical equilibrium. The S-containing species concentrations reach their equilibrium values at significantly shorter time scales than the $\mathrm{N}$ containing species and the CIs. The value of $\tau_{\text {exit }}$ selected to match observed $\mathrm{NO}_{x}$ emission values is rather large and not realistic. Also the combustor inlet temperature selected is higher than in typical engine combustors. This reflects the difficulty in simulating the complex combustion process with a well-mixed reactor. The model succeeds in describing the self-ignition process and is used for some first parameter studies, but more refined model studies are to be performed in the future to simulate the combustion process in more detail.

The amounts of sulfur containing gases and of ions $\mathrm{HSO}_{4}^{-}, \mathrm{SO}_{3}^{-}$, and $\mathrm{NO}_{3}^{-}$depend on the fuel sulfur content. The model results for neutral species and ion mole fractions for two values of FSC are listed in Table 2. The amount of $\mathrm{O}$ leaving the combustor is only $6 \%$ of the amount of $\mathrm{OH}$ radicals, which agrees roughly with equilibrium estimates and implies that the oxidation of $\mathrm{SO}_{2}$ to $\mathrm{SO}_{3}$ with $\mathrm{O}$ is of minor importance compared to reactions with $\mathrm{OH}$ [58]. The computed $\mathrm{NO}_{x}$ emission index is $18 \mathrm{~g} / \mathrm{kg}$ which fits the AERONOX data for the RB211 engine [49] because of
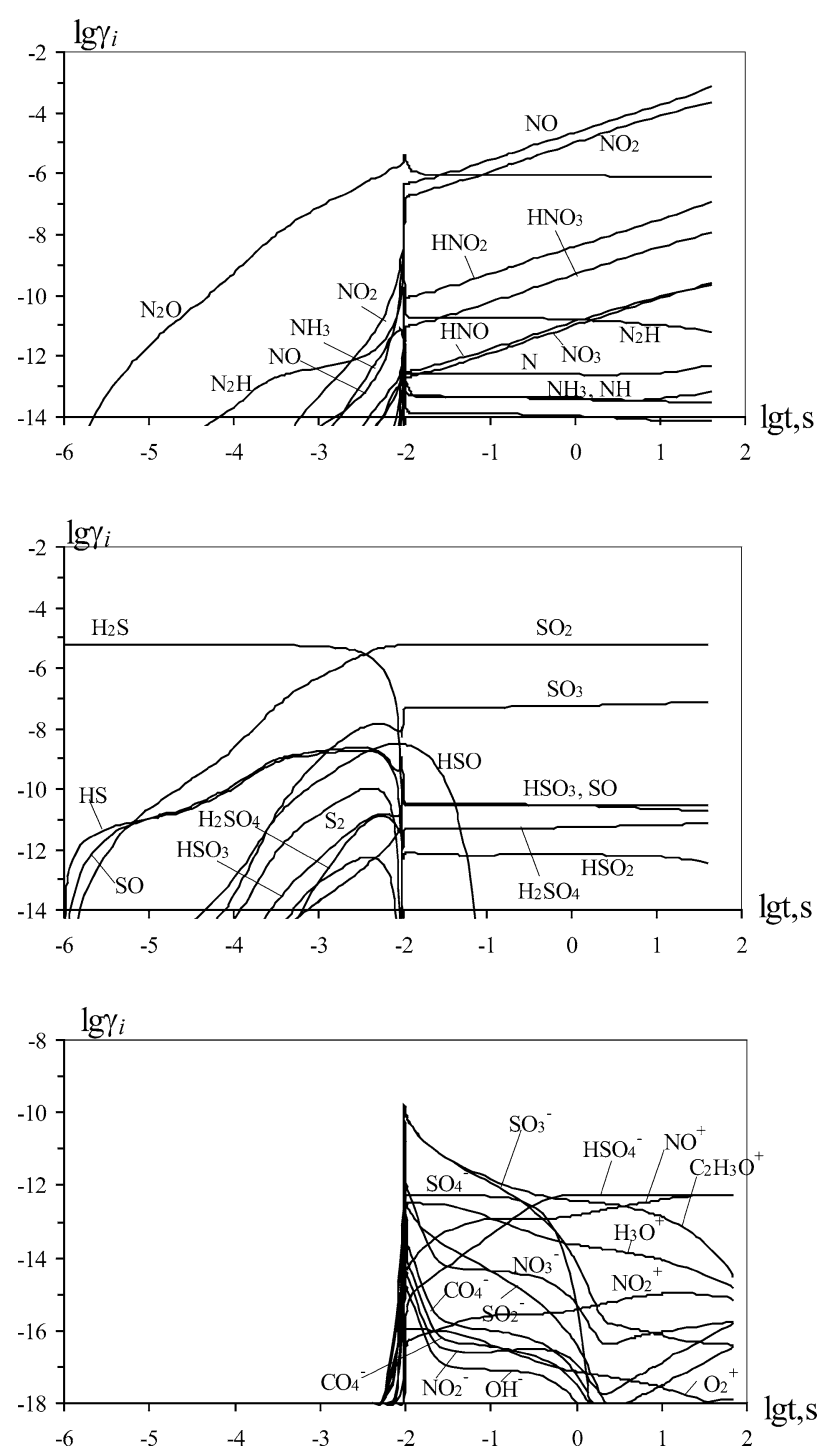

Fig. 1. Evolution of $\mathrm{N}$ - and $\mathrm{S}$-containing gas species and ions mole fractions versus time of combustion for $\mathrm{C}_{8} \mathrm{H}_{18}$ destruction products mixed with air and $\mathrm{H}_{2} \mathrm{~S}$, at fuel/air ratio $\phi=0.25$, temperature $T_{0}=1000 \mathrm{~K}$, pressure $P_{0}=1 \mathrm{MPa}$, and fuel sulfur content $F S C=0.04 \%$.

the selected $\tau_{\text {exit }}$ value. The $\left[\mathrm{NO}_{2}\right] /\left[\mathrm{NO}_{x}\right]$ ratio is close to 0.3 and fairly insensitive to the value of $\tau_{\text {exit }}$ (see Fig. 1a). The ratio is larger than what was measured for the RB211, possibly because of inadequacy of the simple model, but close to what was found for a smaller engine (PW305) in the AERONOX project, and is not unrealistic when compared to measurements in the exhaust plume behind cruising aircraft $[48,52,59]$.

The concentrations of positive and negative ions (and of most gas species) strongly depend on the fuel/air equivalence ratio $\phi$. Note that $\phi$ varies locally within the combustor because of inhomogeneous fuel air mixing and other features of combustion, whereas this study assumes a homogeneous mixture. The temporal evolution of positive and negative ion concentrations versus time is shown in Fig. 2 for $\phi=0.5,0.33$, and 0.25 . The time required for approach- 
Table 2

Neutral gas species and ion mole fractions under combustion of thermal destruction products of the mixture of $\mathrm{C}_{8} \mathrm{H}_{18}$ with air and $\mathrm{H}_{2} \mathrm{~S}$ at $\phi=0.25$, $P_{0}=1 \mathrm{MPa}$, for two values of fuel sulfur content (FSC) of $0.04 \%$ and $0.3 \%$, and for ignition time $\tau_{\text {in }}$ and exit time $\tau_{\text {exit }}$ from the combustor

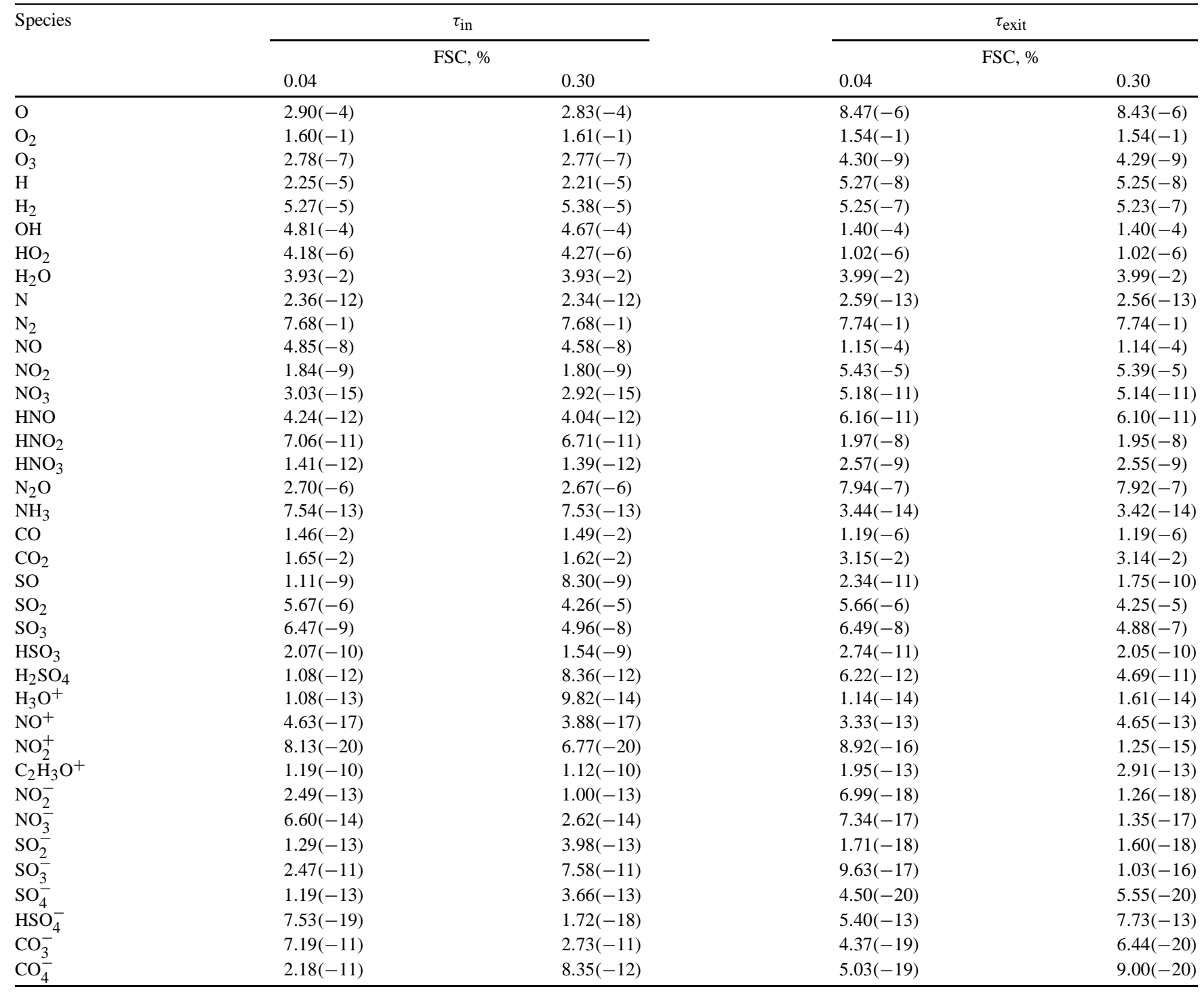

$\mathrm{A}(n)$ corresponds $\mathrm{A} \cdot 10^{n}$.

ing local chemical equilibrium is longer and the CI concentrations (both their maximum values after ignition and their equilibrium ones) are lower for lower values of $\phi$. At $\phi=0.5$, the maximum values of the $\mathrm{HSO}_{4}^{-}$and $\mathrm{NO}^{+}$mixing ratios are around $4 \cdot 10^{-10}$ and the $\mathrm{C}_{2} \mathrm{H}_{3} \mathrm{O}^{+}, \mathrm{H}_{3} \mathrm{O}^{+}, \mathrm{SO}_{3}^{-}$, and $\mathrm{NO}_{3}^{-}$mixing ratios are larger than $10^{-8}$. At $\phi=0.25$, $\mathrm{HSO}_{4}^{-}$reaches a mixing ratio of $5.5 \cdot 10^{-13}$. Hence inhomogeneous mixing, with larger local fuel/air ratio, may also cause larger CI concentrations. The strong dependence of ion concentration from the $\phi$ value is a consequence of larger temperature and larger concentration of $\mathrm{CH}$ radicals after ignition for larger $\phi$ values $(\phi<1)$. Higher temperature and larger $\mathrm{CH}$ concentrations result in larger rates of $\mathrm{CHO}^{+}$ions and electrons formation. An increase of $\phi$ from 0.25 to 0.5 in the model increases the mixing ratio of $\mathrm{CHO}^{+}$and $\mathrm{e}^{-}$ after ignition by nearly a factor of $\sim 10^{4}$. An increase of $\phi$ also causes a larger $\mathrm{O} / \mathrm{OH}$ concentration ratio (the $\mathrm{O} / \mathrm{OH}$ equilibrium ratio is $\sim 0.05,0.1,0.2$, for $\phi=0.25,0.33,0.5$, respectively).

The major reaction paths of ion formation under combustion of S-containing hydrocarbon fuel/air mixtures in our model are identified in Fig. 3. In a first step $\mathrm{CHO}^{+}$ions and electrons form by reactions of $\mathrm{CH}$ radicals in ground electronic state and excited radical $\mathrm{CH}^{*}\left(a^{4} \Sigma\right)$ with $\mathrm{O}$ atoms:

$$
\begin{aligned}
& \mathrm{CH}+\mathrm{O}=\mathrm{CHO}^{+}+\mathrm{e}^{-}, \\
& \mathrm{CH}^{*}\left(a^{4} \Sigma\right)+\mathrm{O}=\mathrm{CHO}^{+}+\mathrm{e}^{-} .
\end{aligned}
$$

The primary negative ions $\mathrm{O}_{2}^{-}$quickly form by associative ionization reactions of electrons and $\mathrm{O}_{2}$ molecules. The $\mathrm{O}_{2}^{-}$ ions react with $\mathrm{CO}_{2}$ and $\mathrm{O}_{2}$ to form $\mathrm{CO}_{4}^{-}$and $\mathrm{O}_{4}^{-}$ions. 

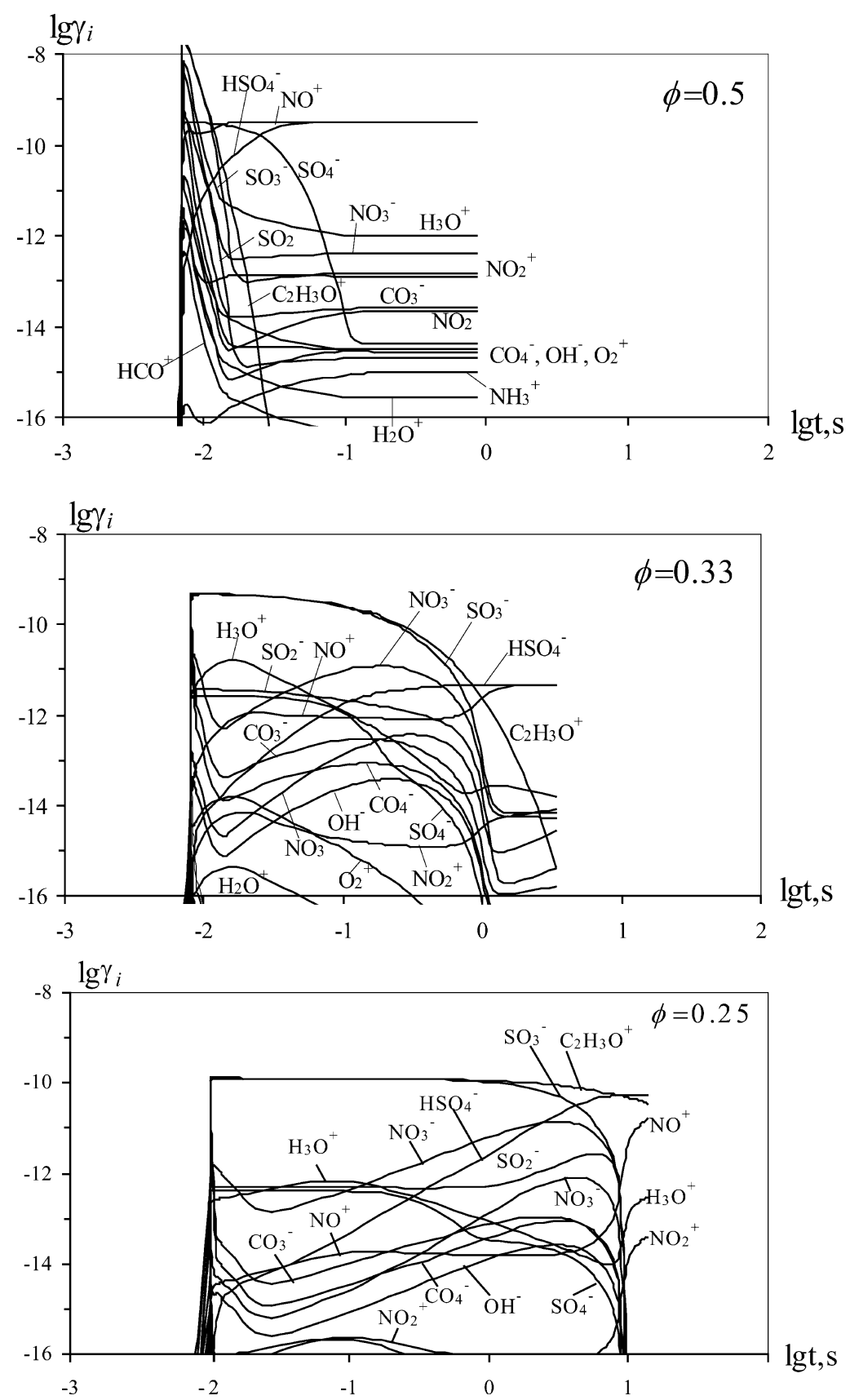

Fig. 2. Evolution of chemiion mole fractions versus time of combustion of $\mathrm{C}_{8} \mathrm{H}_{18}$ destruction products mixed with air and $\mathrm{H}_{2} \mathrm{~S}$ at $T_{0}=1000 \mathrm{~K}, P_{0}=1 \mathrm{MPa}$, $F S C=0.04 \%$ and various values of fuel/air equivalence ratio, $\phi=0.5,0.33$, and 0.25 .

Reactions of $\mathrm{O}_{4}^{-}$ions with $\mathrm{CO}$ molecules and of $\mathrm{CO}_{4}^{-}$ions with $\mathrm{O}$ atoms result in the formation of $\mathrm{CO}_{3}$ and $\mathrm{O}_{3}^{-}$ions. Coincidentally with these processes, the $\mathrm{HCO}^{+}$ions react with $\mathrm{H}_{2} \mathrm{O}$ molecules and $\mathrm{CH}_{2}$ radicals and this results in the rise of $\mathrm{H}_{3} \mathrm{O}^{+}$and $\mathrm{CH}_{3}^{+}$ions. The $\mathrm{H}_{3} \mathrm{O}^{+}$and $\mathrm{CH}_{3}^{+}$ions react with $\mathrm{C}_{2} \mathrm{H}_{2}$ and $\mathrm{H}_{2}$ molecules giving rise to $\mathrm{C}_{3} \mathrm{H}_{3}^{+}$ and $\mathrm{C}_{2} \mathrm{H}_{3} \mathrm{O}^{+}$ions at later times. Reactions of $\mathrm{CO}_{3}^{-}$ions with $\mathrm{O}$ atoms and $\mathrm{SO}_{2}$ molecules produce $\mathrm{O}_{2}^{-}$and $\mathrm{SO}_{3}^{-}$ ions. Reactions of $\mathrm{CO}_{4}^{-}$ions with $\mathrm{SO}_{2}$ and $\mathrm{NO}$ molecules lead to formation of $\mathrm{SO}_{4}^{-}$and $\mathrm{NO}_{2}^{-}$ions. These ions are responsible in this model for the generation of negative ions $\mathrm{SO}_{2}^{-}, \mathrm{HSO}_{4}^{-}$, and $\mathrm{NO}_{3}^{-}$. The positive ions $\mathrm{H}_{2} \mathrm{O}^{+}$, $\mathrm{O}_{2}^{+}, \mathrm{NO}_{2}^{+}$, and $\mathrm{NO}^{+}$form from reactions with $\mathrm{H}_{3} \mathrm{O}^{+}$and $\mathrm{H}_{2} \mathrm{O}^{+}$ions. For negative ions, a similar reaction path scheme has been suggested which includes also the formation of ion clusters $\mathrm{HSO}_{4}^{-} \mathrm{HNO}_{3}$ and $\mathrm{HSO}_{4}^{-} \mathrm{H}_{2} \mathrm{SO}_{4}$ in the exhaust plume outside the engine [23].

Our model computes maximum ion concentrations which may appear small compared to laboratory measurements [10]. Our modeling studies reveal that ion concentrations during combustion decrease mainly by recombination reactions with $\mathrm{C}_{2} \mathrm{H}_{3} \mathrm{O}^{+}$: 


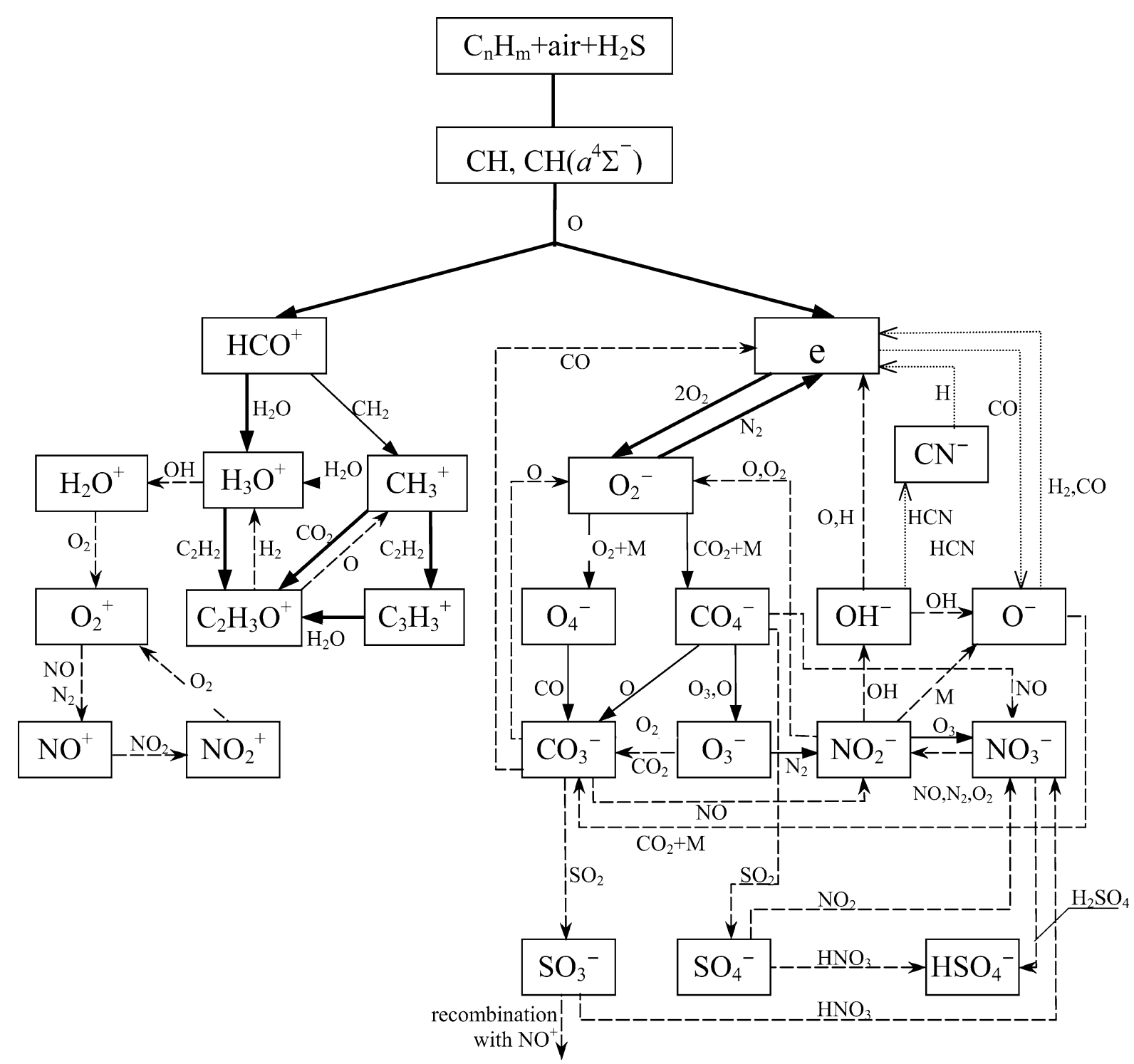

Fig. 3. Scheme of chemiion formation paths under combustion of S-containing hydrocarbon fuels with air. In this scheme solid lines depict the processes of ion formation during ignition time (thick lines correspond to more rapid reactions, and thin lines correspond to slower reactions). Long dashed lines depict the processes of ion formation after ignition time, when the temperature and ion concentration is relatively high. Short dashed lines depict the processes occuring in rich flames $(\phi>1)$.

$$
\begin{aligned}
& \mathrm{SO}_{3}^{-}+\mathrm{C}_{2} \mathrm{H}_{3} \mathrm{O}^{+}=\mathrm{SO}_{3}+\mathrm{C}_{2} \mathrm{H}_{3} \mathrm{O}, \\
& \mathrm{NO}_{3}^{-}+\mathrm{C}_{2} \mathrm{H}_{3} \mathrm{O}^{+}=\mathrm{NO}_{3}+\mathrm{C}_{2} \mathrm{H}_{3} \mathrm{O} .
\end{aligned}
$$

In order to determine an upper limit of ion concentrations in the combustor for the given kinetic reaction scheme, a modified kinetic model is used in which these most important recombination reactions are excluded. In this case, at $\phi=0.25$, the most abundant ions are $\mathrm{HSO}_{4}^{-}$and $\mathrm{C}_{2} \mathrm{H}_{3} \mathrm{O}^{+}$which reach concentrations of $3.9 \cdot 10^{9} \mathrm{~cm}^{-3}$. The values of ion number density at combustor exit, for $\phi=$ 0.25 and $F S C=0.3 \%$, for the two kinetic models, with and without the recombination reactions with $\mathrm{C}_{2} \mathrm{H}_{3} \mathrm{O}^{+}$ differ by a factor of 100, implying an upper limit of ion number density of $4 \cdot 10^{9} \mathrm{~cm}^{-3}$. The ion number density computed with all recombination reactions should be the more realistic one and amounts to $\sim 4 \cdot 10^{7} \mathrm{~cm}^{-3}$. Far larger ion concentrations $\left(>10^{10} \mathrm{~cm}^{-3}\right)$ were measured for $\mathrm{CH}_{4} / \mathrm{O}_{2}$ flames at $\phi=1$ and 0.5 [10]. However for combustion of aviation kerosene with air in lean flames with $\phi=0.25$ the values of ion number density should be significantly smaller, because of the lower combustion temperature. We cannot exclude, however, that other CI source reactions occur which are not included in our model. Differences between our model results and measurements may also result from approximating kerosene by the thermal destruction products of $n-\mathrm{C}_{8} \mathrm{H}_{18}$ with air. In real combustors the combustion of kerosene may lead to another rate of $\mathrm{CH}$ radical formation and result in different $\mathrm{CHO}^{+}$and other ions concentrations. Finally, our model does not account for interactions of the gaseous species and ions with soot. 


\section{Composition of gases and chemiions in the engine}

\subsection{Model for calculation of parameters in the postcombustor flow}

Two models were used to investigate the production of sulfate aerosol precursors and CIs in the flow between combustor and engine exit. The two models differ essentially in the treatment of the flow inside the turbine. The Q1D model [46] treats the temperature, pressure, velocity and gas composition according to the one-dimensional conservation principles along the flow through the turbine, including blade effects. The second model is a box model in which temperature and pressure is prescribed as a function of time [58]. In this box model study, it was assumed that the temperature decreases linearly from combustor exit to nozzle exit and that the pressure decreases faster according to a prescribed hyperbolic function of time along the flow. We study the change in gas and ion concentrations along the engine duct and the implications of such box model simplifications for conditions approximating the core of engines of type $R B 211$ and $J T 9 D-7 A$, as used for $B$ 757 and $B-747$ subsonic aircraft. The same engines have been considered in previous modeling and experimental studies [46,58]. The boundary conditions ( $T, P$ and gas composition) at combustor exit for these calculations are taken from the combustion calculations for $\phi=0.25 ; T_{0}=$ $1000 \mathrm{~K} ; P_{0}=1 \mathrm{MPa}$ described in the previous section (Table 2).

Fig. 4 depicts the evolution of temperature $T_{\mathrm{r}}$ and pressure $P_{\mathrm{r}}$ with time after exit from the combustor as computed with the Q1D model (full curve) inside the turbine for the RB211 engine under cruise condition of a $B-747$ aircraft (altitude $H=10.7 \mathrm{~km}$, Mach number $M_{0}=0.8$ ). The linear temperature approximation, represented by the dashed line, deviates considerably from the Q1D result. Fig. 5 depicts the evolution of the $\mathrm{H}-, \mathrm{N}-$, and S-containing gas species concentrations computed with the Q1D model inside the engine for two different FSC values.

The values of mole fractions $\gamma_{i}$ of neutral species and CIs, temperature, and pressure during the postcombustor flow versus time $t$ at characteristic cross sections of the internal flow are listed in Table 3 for $F S C=0.3 \%$. The temperature decreases from $1540 \mathrm{~K}$ at combustor exit to $598 \mathrm{~K}$ at nozzle exit. The mole fractions $\gamma_{i}$ vary considerably for most of the components with minor variations only for $\mathrm{H}_{2} \mathrm{O}, \mathrm{O}_{2}, \mathrm{~N}_{2}$, and $\mathrm{CO}_{2}$. The variations of the $\gamma_{i}$ values are most pronounced for strong oxidizers such as $\mathrm{O}, \mathrm{OH}$, and $\mathrm{HO}_{2}$, as well as for $\mathrm{NO}_{3}$ and for members of the $\mathrm{N}_{x} \mathrm{H}_{y}$ group. The effective mass emission index of $\mathrm{OH}$ amounts to $5.4 \mathrm{~g} / \mathrm{kg}$ at combustor exit and $66 \mathrm{mg} / \mathrm{kg}$ at engine exit. At engine exit, most of the initially formed $\mathrm{OH}$ radicals are depleted by reactions with $\mathrm{NO}, \mathrm{NO}_{2}, \mathrm{SO}_{2}$ and others, leaving a mole fraction of about $10^{-6}$, and this explains why measurements so far found hardly significant traces of $\mathrm{OH}$ at engine exit [6]. From measurements of $\mathrm{HNO}_{2}, \mathrm{HNO}_{3}, \mathrm{NO}$, and $\mathrm{NO}_{2}$ in aged exhaust plumes, $\mathrm{OH}$ emission indices of 60 to $400 \mathrm{mg} / \mathrm{kg}$ have been derived using models describing the chemistry in the diluting plume, starting from engine exit [52,59]. This fits reasonably with the present model results. The small amount of $\mathrm{OH}$ emitted from the engine exit implies small $(<1 \%)$ additional sulfur conversion to $\mathrm{H}_{2} \mathrm{SO}_{4}$ after engine exit [59]. It should be noted that the concentrations of $\mathrm{HNO}_{2}$ and $\mathrm{HNO}_{3}$ in the turbine affect each other (Fig. 5; see [46]). The local maximum in $\mathrm{HNO}_{3}$ near $t=1.8 \mathrm{~ms}$ is caused by a change in importance of various reactions at this time. At early stage of expansion in the turbine $(t \leqslant 1.8 \mathrm{~ms})$, the increase in $\mathrm{HNO}_{3}$ is caused mainly by the reactions $\mathrm{NO}_{2}+\mathrm{OH}+\mathrm{M}=\mathrm{HNO}_{3}+\mathrm{M}$ and $\mathrm{O}_{2}+\mathrm{HNO}_{2}=\mathrm{O}+\mathrm{HNO}_{3}$. After $t=1.8 \mathrm{~ms}$, the decrease

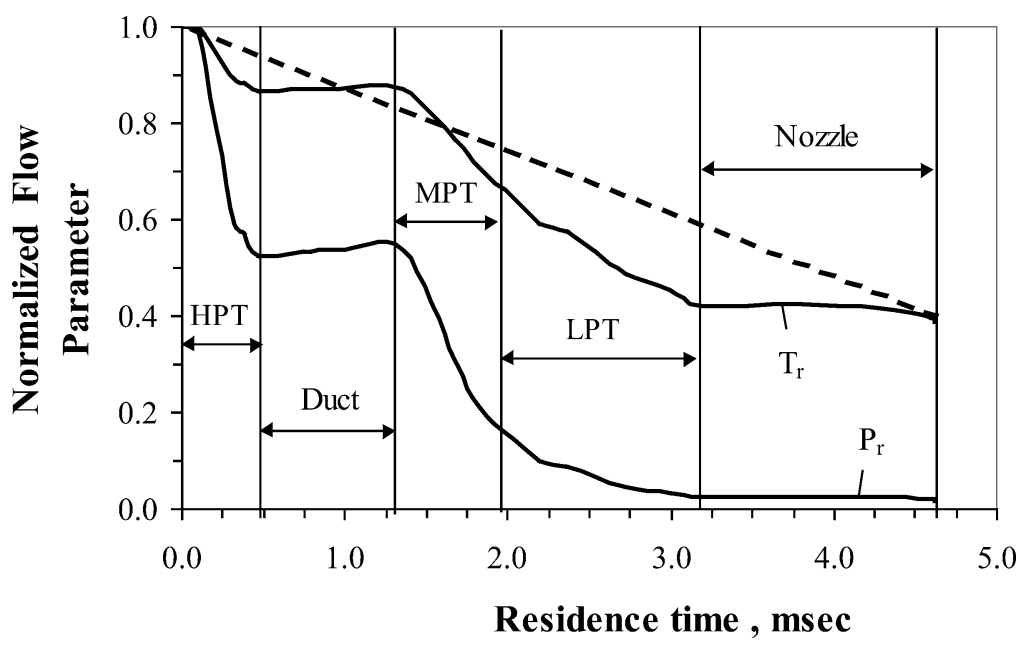

Fig. 4. Temperature and pressure evolution in the flow from the combustor exit to engine exit within an $R B 211$ core engine at cruise conditions of a $B-747$ aircraft. Solid lines correspond to temperature $T$ and pressure $P$ as obtained by simulation of the postcombustor flow using the Q1D model, and the dotted line depicts a linear variation of $T$ with time. The values are normalized by the initial values. Arrows indicate the ranges of the high-pressure turbine (HPT), the duct between high- and medium-pressure turbines, the medium-pressure turbine (MPT), the three-stage low-pressure turbine (LPT), and the exhaust nozzle until nozzle exit. 

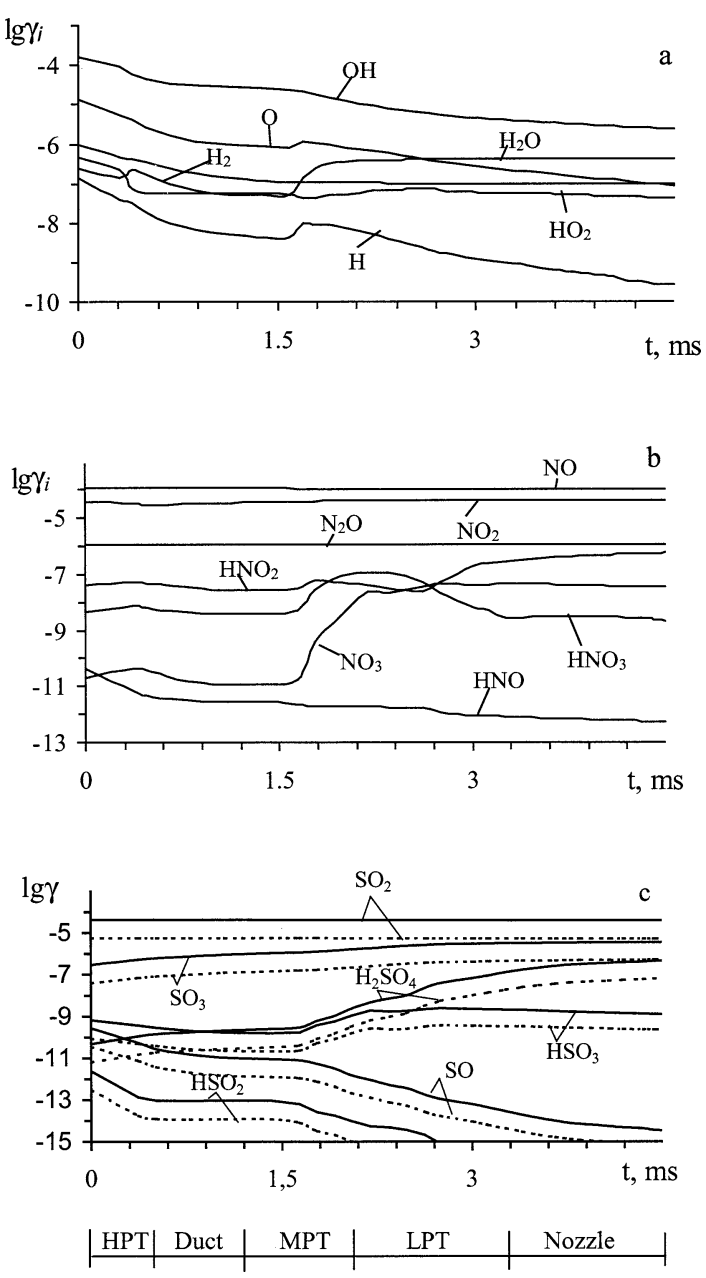

Fig. 5. H- (a), N- (b), and S-containing (c) gas species mole fractions in the postcombustor flow of a $R B 211$ engine at $F S C=0.04 \%$ (dashed curves) and $F S C=0.3 \%$ (solid curves).

of $\mathrm{HNO}_{3}$ concentration and the formation of $\mathrm{NO}_{3}$ is caused mainly by the reactions $\mathrm{HNO}_{3}+\mathrm{OH}=\mathrm{NO}_{3}+\mathrm{H}_{2} \mathrm{O}$ and $\mathrm{HNO}_{3}+\mathrm{M}=\mathrm{H}+\mathrm{NO}_{3}+\mathrm{M}$.

Significant $\mathrm{SO}_{2}$ oxidation occurs throughout the turbine resulting in up to $9 \%$ oxidation of the total $\mathrm{SO}_{x}$ to $\left(\mathrm{SO}_{3}+\mathrm{H}_{2} \mathrm{SO}_{4}\right)$ at engine exit for $F S C=0.04 \%$, and $8.4 \%$ conversion for $F S C=0.3 \%$. The $\mathrm{NO}_{3}$ and $\mathrm{HNO}_{2}$ concentrations also increase significantly within the postcombustor flow but stay below $1 \%$ of the sum of $\mathrm{NO}$ and $\mathrm{NO}_{2}$ species, as found in measurements $[1,52,58]$.

At nozzle exit, $\mathrm{NO}^{+}$and $\mathrm{HSO}_{4}^{-}$ions are the most abundant ones. The presence of $\mathrm{HSO}_{4}^{-}$ions is consistent with recent mass spectrometric measurements after engine exit $[32,33]$. However, $\mathrm{NO}^{+}$ions were not observed within these measurements. These measurements identified only ions with masses larger than 50 atomic mass units. It is well known that $\mathrm{NO}^{+}$ions may be generated in large amounts in shock waves in air [34,40]. $\mathrm{NO}^{+}$ions were also observed in $\mathrm{H}_{2} /$ air flames [25] and in acetylene and propane/air flames [22]. The model does not take into account the formation of $\mathrm{NO}^{+}\left(\mathrm{H}_{2} \mathrm{O}\right)_{n}$ clusters and their possible reactions with molecules possessing proton affinities larger than that of $\mathrm{H}_{2} \mathrm{O}$ [33]. Ions $\mathrm{NO}^{+}\left(\mathrm{H}_{2} \mathrm{O}\right)_{n}$ are presumably unstable at the high temperatures inside the engine but may form in the cool exhaust plume outside the engine.

The mole fractions of the major ions and the sum of all ions does not vary much along the duct in the model (see Table 3). Instead, the total ion concentration is controlled mainly by the amount of ions formed in the combustion chamber, because the recombination time is much larger than the transit time within the postcombustor duct for the given concentrations. For larger initial ion concentrations at combustor exit, ion-ion-recombination reactions in the turbine would be more important. As it was mentioned above, the computed ion concentration at combustor exit strongly depends on the treatment of recombination reactions with $\mathrm{C}_{2} \mathrm{H}_{3} \mathrm{O}^{+}$in the kinetic model. The recombination reactions inside the combustor reduce the ion concentrations at nozzle exit by a factor of order of 100 . Without these recombinations, the ion concentration sum would reach an upper limit of $4.3 \cdot 10^{8} \mathrm{~cm}^{-3}$, corresponding to an emission factor of $2.3 \cdot 10^{17} \mathrm{~kg}^{-1}$. However the recombination reactions do occur and hence the sum of the ion concentration (maximum for $\mathrm{HSO}_{4}^{-}$) amounts to only about $4.5 \cdot 10^{6} \mathrm{~cm}^{-3}$ at nozzle exit at cruise or an ion emission index of $2 \cdot 10^{15} \mathrm{~kg}^{-1}$ in our model. This is less than expected from measurements at the ground $[2,4]$ and less than required to explain the number of volatile particles formed with models [29].

The larger observed ion concentration at ground may be explained partly by different engine operation conditions at ground compared to cruise altitude. Another possible reason results from local variations in the fuel/air ratio within real combustors. The details of the flow inside the combustor are very complicated and not represented in our model. Variations in the fuel/air ratios within the combustor $(\phi=1 / 0.2)$ could cause locally higher temperature and larger ion concentration. The temperature and pressure at the combustor inlet at ground is higher than at cruise altitude. Moreover, engines at ground are operating with higher fuel/air ratios than during cruise. At ground, with $T_{0}=1250 \mathrm{~K}, P_{0}=4.5 \mathrm{MPa}$ at combustor inlet and $P=0.082 \mathrm{MPa}$ and $T \approx 750 \mathrm{~K}$ at engine exit, and $\phi=0.33$, the model calculates a positive ion concentration at engine exit of about $9.4 \cdot 10^{7} \mathrm{~cm}^{-3}$, about 70 times larger than at cruise. This result is larger than the total negative CI concentration of $1.4 \cdot 10^{7} \mathrm{~cm}^{-3}$ measured with a mass spectrometer and a little less than the total positive CI concentration of $1.6 \cdot 10^{8} \mathrm{~cm}^{-3}$ measured with an electrostatic probe about $10 \mathrm{~ms}$ behind the ATTAS jet engine at ground $[2,4]$. For $\phi=0.25$ at ground, the computed total ion number density at combustor exit is about $1.7 \cdot 10^{9} \mathrm{~cm}^{-3}$, i.e. the reduction of $\phi$ from 0.33 to 0.25 decreases positive ions at engine exit to about $3.8 \cdot 10^{7} \mathrm{~cm}^{-3}$, still 30 times larger than at cruise.

Our calculations (see Table 2) show also that the ion composition depends on the fuel sulfur content. An increase of FSC results in a significant, but less than linear decrease 
Table 3

Postcombustor flow age, temperature, pressure, and gas composition mixing ratios at the different sections of a $R B 211$ engine under cruise conditions of a $B-747$ aircraft with $F S C=0.3 \%$

\begin{tabular}{|c|c|c|c|c|c|}
\hline & $\begin{array}{c}\text { Combustor } \\
\text { exit }\end{array}$ & $\begin{array}{l}\text { High pressure turbine } \\
\text { exit }\end{array}$ & $\begin{array}{l}\text { Middle pressure turbine } \\
\text { exit }\end{array}$ & $\begin{array}{l}\text { Low pressure turbine } \\
\text { exit }\end{array}$ & $\begin{array}{l}\text { Exit nozzle } \\
\text { plane }\end{array}$ \\
\hline$t, \mathrm{~ms}$ & 0 & 0.45 & 1.8 & 3.2 & 4.6 \\
\hline$T, \mathrm{~K}$ & 1540 & 1330 & 1100 & 650 & 598 \\
\hline $\mathrm{O}$ & $8.43(-6)$ & $1.34(-6)$ & $5.94(-7)$ & $1.30(-7)$ & $4.47(-8)$ \\
\hline $\mathrm{O}_{2}$ & $1.54(-1)$ & $1.54(-1)$ & $1.54(-1)$ & $1.54(-1)$ & $1.54(-1)$ \\
\hline $\mathrm{O}_{3}$ & $4.30(-9)$ & $2.15(-9)$ & $3.49(-9)$ & $5.37(-8)$ & $9.17(-8)$ \\
\hline $\mathrm{OH}$ & $1.40(-4)$ & $3.42(-5)$ & $1.42(-5)$ & $3.08(-6)$ & $1.71(-6)$ \\
\hline $\mathrm{HO}_{2}$ & $1.01(-6)$ & $3.46(-8)$ & $6.93(-9)$ & $4.22(-8)$ & $3.19(-8)$ \\
\hline $\mathrm{H}_{2} \mathrm{O}$ & $3.99(-2)$ & $3.99(-2)$ & $3.99(-2)$ & $3.99(-2)$ & $3.99(-2)$ \\
\hline $\mathrm{N}$ & $2.56(-13)$ & $1.64(-15)$ & $4.17(-17)$ & $2.01(-20)$ & $4.09(-21)$ \\
\hline $\mathrm{N}_{2}$ & $7.74(-1)$ & $7.74(-1)$ & $7.74(-1)$ & $7.74(-1)$ & $7.74(-1)$ \\
\hline $\mathrm{HNO}_{3}$ & $2.53(-9)$ & $6.80(-9)$ & $2.73(-8)$ & $6.20(-10)$ & $3.90(-10)$ \\
\hline $\mathrm{N}_{2} \mathrm{O}$ & $7.92(-7)$ & $7.82(-7)$ & $7.59(-7)$ & $7.58(-7)$ & $7.58(-7)$ \\
\hline $\mathrm{NH}_{3}$ & $3.42(-14)$ & $6.97(-15)$ & $1.20(-15)$ & $1.08(-15)$ & $1.08(-15)$ \\
\hline $\mathrm{CO}$ & $2.18(-6)$ & $1.44(-6)$ & $9.46(-7)$ & $9.19(-7)$ & $9.16(-7)$ \\
\hline $\mathrm{CO}_{2}$ & $3.14(-2)$ & $3.14(-2)$ & $3.14(-2)$ & $3.14(-2)$ & $3.14(-2)$ \\
\hline $\mathrm{SO}$ & $1.75(-10)$ & $1.27(-11)$ & $2.11(-12)$ & $1.27(-14)$ & $1.29(-15)$ \\
\hline $\mathrm{SO}_{2}$ & $4.25(-5)$ & $4.22(-5)$ & $4.15(-5)$ & $4.00(-5)$ & $3.94(-5)$ \\
\hline $\mathrm{SO}_{3}$ & $4.88(-7)$ & $7.74(-7)$ & $1.47(-6)$ & $2.87(-6)$ & $3.13(-6)$ \\
\hline $\mathrm{HSO}_{3}$ & $2.23(-10)$ & $2.14(-10)$ & $4.89(-10)$ & $1.53(-9)$ & $8.79(-10)$ \\
\hline $\mathrm{H}_{2} \mathrm{SO}_{4}$ & $4.69(-11)$ & $1.82(-10)$ & $1.00(-9)$ & $1.34(-7)$ & $4.63(-7)$ \\
\hline $\mathrm{H}_{3} \mathrm{O}^{+}$ & $1.61(-14)$ & $1.54(-14)$ & $1.49(-14)$ & $1.49(-14)$ & $1.49(-14)$ \\
\hline $\mathrm{NO}^{+}$ & $4.65(-13)$ & $4.67(-13)$ & $4.67(-13)$ & $4.67(-13)$ & $4.67(-13)$ \\
\hline $\mathrm{HSO}_{4}^{-}$ & $7.73(-13)$ & $7.73(-13)$ & $7.73(-13)$ & $7.73(-13)$ & $7.73(-13)$ \\
\hline $\mathrm{CO}_{3}^{-4}$ & $6.44(-20)$ & $5.43(-21)$ & $3.00(-21)$ & $3.64(-22)$ & $9.46(-23)$ \\
\hline $\mathrm{CO}_{4}^{-}$ & $9.00(-20)$ & $4.50(-20)$ & $4.73(-20)$ & $2.92(-20)$ & $1.14(-20)$ \\
\hline
\end{tabular}

$\mathrm{A}(n)$ corresponds $\mathrm{A} \cdot 10^{n}$.

of $\mathrm{NO}_{3}^{-}$and $\mathrm{NO}_{2}^{-}$concentrations and a slight increase of $\mathrm{NO}^{+}$and $\mathrm{HSO}_{4}^{-}$concentrations at nozzle exit.

\subsection{The conversion of fuel sulfur to $\mathrm{SO}_{3}$ and $\mathrm{H}_{2} \mathrm{SO}_{4}$}

In this section we compare our model with that used in a previous study [58] and investigate the sensitivity of the conversion fraction $\varepsilon$ to the initial conversion of $\mathrm{SO}_{2}$ to $\mathrm{SO}_{3}$ inside the combustor and to the thermodynamic profiles between combustor exit and engine exit. The previous study investigated the sulfur conversion chemistry in the turbine of a JT9D-7A engine, as used on older B747 aircraft, for which measurements had been reported previously for $F S C=0.0085 \%$ [59]. The combustor exit temperature and pressure for this engine are $T_{\mathrm{c}}=1200 \mathrm{~K}$ and $P_{\mathrm{c}}=0.77 \mathrm{MPa}$. In the box model the temperature and pressure profiles between combustor exit and engine exit have to be prescribed. The previous study assumed a linear temperature profile and a hyperbolic pressure profile as a function of time approaching $621 \mathrm{~K}$ and $P_{\mathrm{c}}=301 \mathrm{hPa}$ at nozzle exit. In this paper, we use the same initial conditions at combustor exit with gas composition as given in column 2 of Table 4. Using our kinetic scheme in such a box model gives a conversion fraction $\varepsilon=3.3 \%$. This value is close to the result $\varepsilon=3.8 \%$ obtained earlier [58]. In view of small differences in the model kinetics and the high sensitivity of such models to the kinetics, in particular to the reaction rate of $\mathrm{SO}_{2}$ with $\mathrm{OH}$, this is to be considered a good agreement. If the same model is 
Table 4

Gas species mole fractions and conversion fraction $\varepsilon$ at combustor exit and at engine exit for a $J T 9 D-7 A$ engine computed with the present kinetic model and with prescribed combustor exit data and temperature and pressure profiles inside the turbine duct as used in a previous study [58]

\begin{tabular}{lcc}
\hline Species & Combustor exit & Engine exit \\
\hline $\mathrm{H}$ & $5.06(-18)$ & $6.44(-10)$ \\
$\mathrm{H}_{2}$ & $2.03(-15)$ & $1.82(-7)$ \\
$\mathrm{O}$ & $1.80(-7)$ & $6.68(-8)$ \\
$\mathrm{O}_{2}$ & $1.98(-1)$ & $1.98(-1)$ \\
$\mathrm{OH}$ & $9.01(-6)$ & $2.69(-6)$ \\
$\mathrm{HO}_{2}$ & $4.05(-8)$ & $2.43(-9)$ \\
$\mathrm{H}_{2} \mathrm{O}$ & $3.14(-2)$ & $3.14(-2)$ \\
$\mathrm{N}_{2}$ & $7.38(-1)$ & $7.38(-1)$ \\
$\mathrm{NO}$ & $2.20(-4)$ & $2.07(-4)$ \\
$\mathrm{NO}_{2}$ & $4.15(-5)$ & $5.37(-5)$ \\
$\mathrm{NO}_{3}$ & $2.03(-20)$ & $2.40(-8)$ \\
$\mathrm{HNO}$ & $2.03(-19)$ & $4.78(-14)$ \\
$\mathrm{HNO}_{2}$ & $2.03(-20)$ & $3.45(-7)$ \\
$\mathrm{HNO}_{3}$ & $2.03(-20)$ & $1.63(-9)$ \\
$\mathrm{N}_{2} \mathrm{O}$ & $2.03(-20)$ & $5.96(-10)$ \\
$\mathrm{CO}_{\mathrm{CO}}$ & $1.44(-5)$ & $1.42(-5)$ \\
$\mathrm{CH}_{4}$ & $3.22(-2)$ & $3.22(-2)$ \\
$\mathrm{SO}_{2}$ & $2.62(-6)$ & $2.01(-6)$ \\
$\mathrm{SO}_{3}$ & $1.20(-6)$ & $1.16(-6)$ \\
$\mathrm{HSO}_{3}$ & $2.03(-19)$ & $3.87(-8)$ \\
$\mathrm{H}_{2} \mathrm{SO}_{4}$ & $2.03(-25)$ & $3.09(-11)$ \\
$\varepsilon, \%$ & $2.03(-19)$ & $5.67(-10)$ \\
\hline $\mathrm{A}$ & 0 & 3.27 \\
\hline
\end{tabular}

$\mathrm{A}(n)$ corresponds $\mathrm{A} \cdot 10^{n}$.

run with initial conditions taken from our combustor model, with $0.69 \%$ of the sulfur molecules converted to $\mathrm{SO}_{3}$ already at combustor exit, the model computes $\varepsilon=3.92 \%$ at nozzle exit, which is $0.65 \%$ more than with zero initial $\mathrm{SO}_{3}$. This confirms that the initial $\mathrm{SO}_{3}$ adds about linearly to the amount of $\mathrm{SO}_{3}+\mathrm{H}_{2} \mathrm{SO}_{4}$ available at engine exit.

In order to determine the influence of the temperature profile in the turbine on the sulfur chemistry, we run our kinetic model for the RB211 engine using either the temperature profile computed by our Q1D model or a linearly decreasing temperature profile. The two cases were run for the combustor exit conditions listed in column 2 of Table 3. For the linear temperature profile, the model computes $\varepsilon=2.72 \%$; for the temperature profile from the Q1D model, the result is $\varepsilon=8.36 \%$. The differences in Scontaining gas concentrations and the conversion fraction caused by the linear approximation in comparison to the nonlinear model are significant (up to a factor of 3 ). A strong impact of flow dynamics and the temperature profile on $\varepsilon$ has been found also by others $[36,39]$.

\section{Conclusions}

The formation of gaseous sulfate aerosol precursors and ions in the combustor and in the turbine of an aircraft engine has been simulated. The combustor model simulates the transient combustion of S-containing hydrocarbon fuels with air in a closed adiabatic reactor under conditions close to those in aircraft engine combustors. The turbine flow is computed with a quasi one-dimensional flow model. Both models include new gas species and ion kinetic models. This is the first published model study of ion formation inside an aircraft engine.

The concentrations of ions depend strongly on the fuel/air equivalence ratio $\phi$ and also, but less than linearly, on the fuel sulfur content. The total ion mole fraction stays close to constant in the turbine section of the engine in this model. The computed positive ion (mainly $\mathrm{NO}^{+}$) concentrations at engine exit of $1.39 \cdot 10^{6} \mathrm{~cm}^{-3}$ for cruise regime is 100 times less than the concentration expected from positive ion measurements at the ground with an electrostatic probe [4]. The corresponding total ion concentration of about $4.5 \cdot 10^{6} \mathrm{~cm}^{-3}$ corresponds to a total ion emission index of $2 \cdot 10^{15} \mathrm{~kg}^{-1}$. This value is also 100 times less than what has been derived from aerosol measurements with CI-driven nucleation models [29]. For ground conditions, with higher pressure and temperature at combustor inlet and higher fuel/air ratio, the computed total number density of positive and negative ions is 70 times larger and about $\sim 10^{8} \mathrm{~cm}^{-3}$ which is not far off the value measured [4]. This indicates a strong dependence of CI emission on the type and operation of the engines.

Larger ion concentrations would occur, in particular in the combustor, if the recombination rate in the combustor is smaller than assumed in the model. Also peculiarities of turbulent combustion with locally inhomogeneous fuel/air ratios in the various parts of the combustor are expected to cause larger ion concentrations. This needs to be investigated with three-dimensional combustion models in the future. Finally, further important CI formation processes may exist which are not included in the model. Because of selflimitation of the ion concentration by recombination, the engine dependence could be weaker for higher CI emissions from the combustor.

Most of the relevant $\mathrm{H}-, \mathrm{N}$ - and some of the $\mathrm{S}$-species do not reach chemical equilibrium in the combustors. Most of the oxidation of fuel sulfur to $\mathrm{SO}_{3}$ and $\mathrm{H}_{2} \mathrm{SO}_{4}$ occurs in the turbine between the combustor and engine exit. A small fraction of the $\mathrm{SO}_{3}$ is formed already inside the combustor. The conversion in the combustor adds about linearly to the $\varepsilon$ value at engine exit. The sulfur conversion fraction $\varepsilon$ in an $R B 211$ engine is computed by this model to be $\approx 9 \%$, and $\approx 8.4 \%$, for FSC of $0.04 \%$ and $0.3 \%$, respectively. Hence, an increase in FSC causes a minor reduction in $\varepsilon$. The results of the present sulfur chemistry kinetics agree well with those of a previous study [58] if applied with the same temperature and pressure profiles and the same initial conditions, though both models may suffer from uncertainties in the sulfur kinetics. The sulfur conversion fraction $\varepsilon$ depends strongly on the temperature profile along the flow within the engine. The assumption of a linear temperature profile in the turbine may cause an underestimate of $\varepsilon$ by a factor of 3 . 


\section{Acknowledgements}

This work was supported within the CHEMICON project by the Environment and Climate Research Program of EC under grant ENV4-CT97-0620 and by the Russian Foundation for Basic Research under grant 99-01-01165.
We thank Hans Georg Tremmel for providing details of his calculation results for comparison and Frank Arnold and Reinhold Zellner for helpful discussions.

\section{Appendix A. Kinetic mechanisms}

Table A1

Kinetic mechanism for S-containing gas species formation

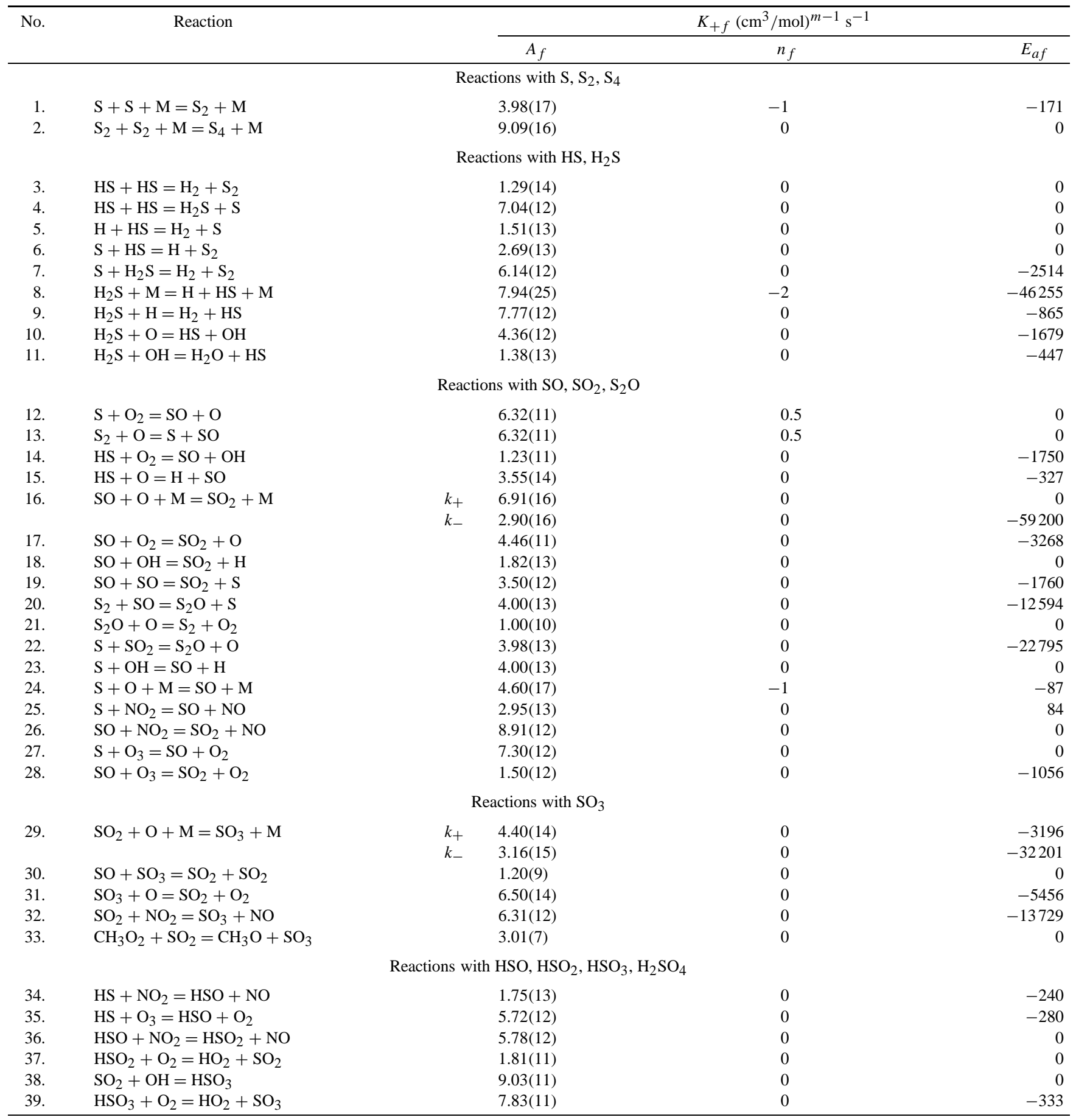




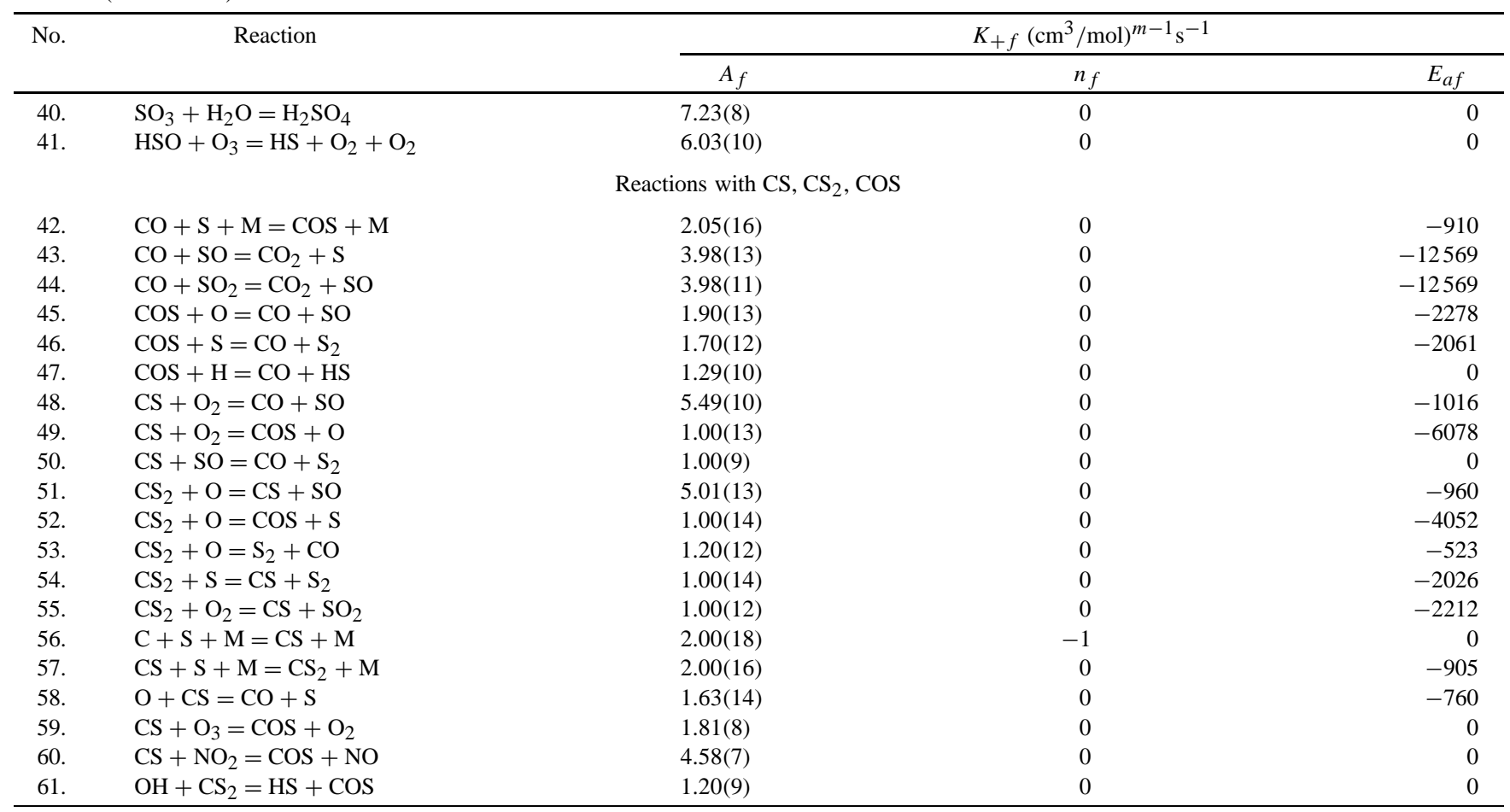

$\mathrm{A}(n)$ corresponds to $\mathrm{A} \cdot 10^{n} \cdot K_{f}=A_{f} \cdot T^{n} f \exp \left(E_{a f} / T\right), m$ is the number of molecules participating in the reaction. Reactions (1)-(22), (34)-(37), (42)-(55), (58)-(61) were taken from [44]; (23), (29)-(31), (40) from [9]; (24)-(26), (41) from [26]; (27)-(28), (56)-(57) from [47]; (32) from [60]; (33) from [36]; (38), (39) from [16].

Table A2

Reaction mechanism for chemi-ions formation during combustion of S-containing hydrocarbons and air mixtures

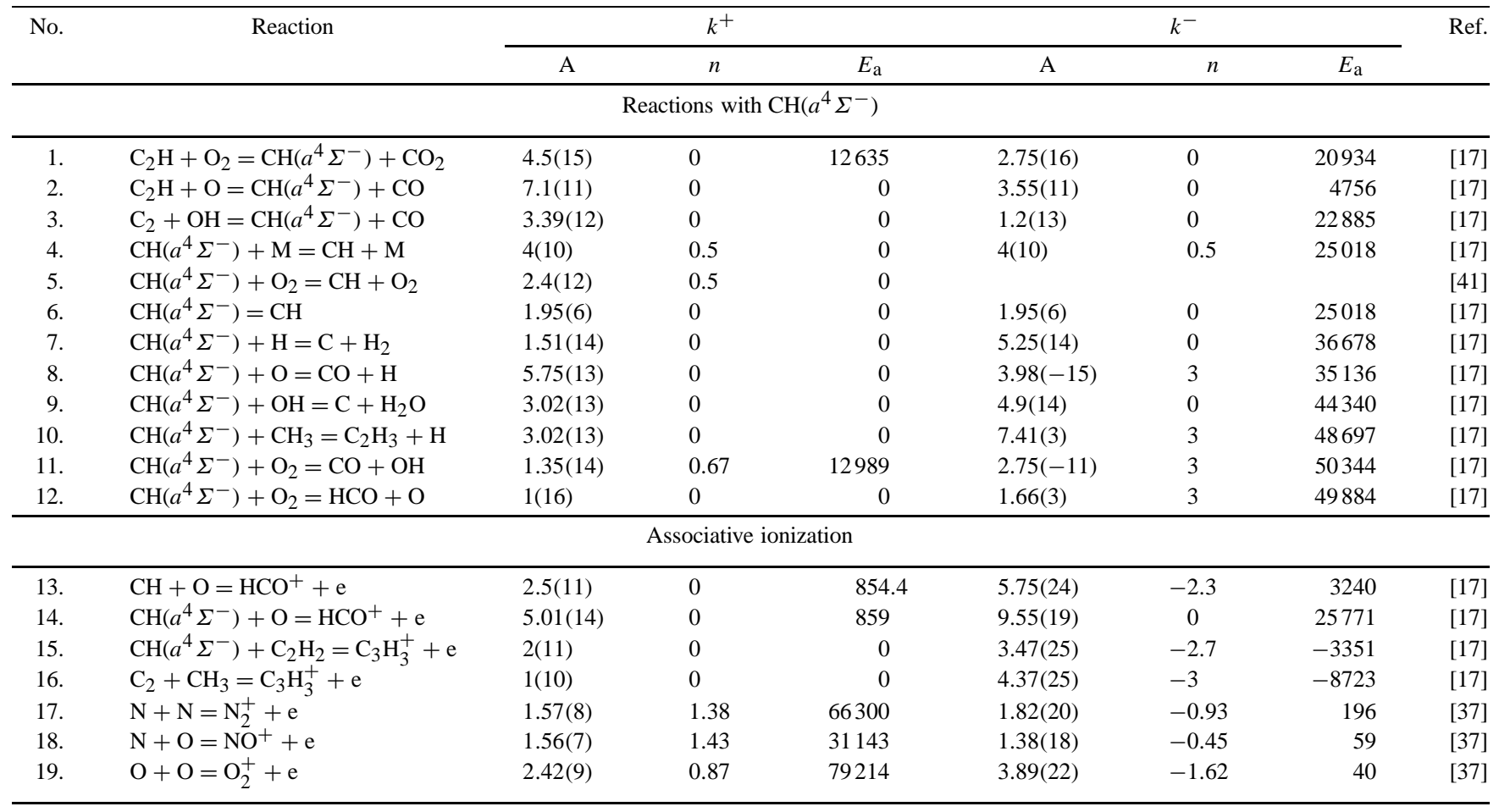

Dissociative ionization

\begin{tabular}{llllllll}
20. & $\mathrm{O}_{3}+\mathrm{e}=\mathrm{O}_{2}^{-}+\mathrm{O}$ & $6(14)$ & 0 & 0 & $9(13)$ & 0 & 0 \\
\hline
\end{tabular}




\begin{tabular}{|c|c|c|c|c|c|c|c|c|}
\hline \multirow[t]{2}{*}{ No. } & \multirow[t]{2}{*}{ Reaction } & \multicolumn{3}{|c|}{$\mathrm{k}^{+}$} & \multicolumn{3}{|c|}{$\mathrm{k}^{-}$} & \multirow[t]{2}{*}{ Ref. } \\
\hline & & A & $n$ & $E_{\mathrm{a}}$ & A & $n$ & $E_{\mathrm{a}}$ & \\
\hline 21. & $\mathrm{~N}_{2} \mathrm{O}+\mathrm{e}=\mathrm{N}_{2}+\mathrm{O}^{-}$ & $1.2(14)$ & 0 & 0 & $1.2(5)$ & 0 & 0 & [55] \\
\hline 22. & $\mathrm{HNO}_{3}+\mathrm{e}=\mathrm{NO}_{2}^{-}+\mathrm{OH}$ & $3(16)$ & 0 & 0 & & & & {$[30]$} \\
\hline 23. & $\mathrm{CO}+\mathrm{e}=\mathrm{C}+\mathrm{O}^{-}$ & $1.8(10)$ & 0 & 0 & 0 & 0 & 0 & {$[55]$} \\
\hline \multicolumn{9}{|c|}{ Ionization under molecule and electron interaction } \\
\hline 24. & $\mathrm{~N}_{2}+\mathrm{e}=\mathrm{N}_{2}^{+}+\mathrm{e}+\mathrm{e}$ & $2.19(-8)$ & 5.04 & 180840 & $1.5(5)$ & 2.56 & 2446 & [37] \\
\hline 25 . & $\mathrm{N}+\mathrm{e}=\mathrm{N}^{+}+\mathrm{e}+\mathrm{e}$ & $1.8(13)$ & 0.6 & 168772 & $2.61(19)$ & -0.5 & -6663 & [37] \\
\hline 26. & $\mathrm{NO}+\mathrm{e}=\mathrm{NO}^{+}+\mathrm{e}+\mathrm{e}$ & $6.46(23)$ & -1.68 & 107367 & $1.96(33)$ & -3.34 & 418 & [37] \\
\hline 27. & $\mathrm{O}_{2}+\mathrm{e}=\mathrm{O}_{2}^{+}+\mathrm{e}+\mathrm{e}$ & $1(-13)$ & 6.02 & 140150 & $9.40(-3)$ & 3.84 & 3478 & [37] \\
\hline 28. & $\mathrm{O}+\mathrm{e}=\mathrm{O}^{+}+\mathrm{e}+\mathrm{e}$ & $5.2(12)$ & 0.68 & 157981 & $1(22)$ & -1.04 & -4544 & [37] \\
\hline \multicolumn{9}{|c|}{ Associative electron attachment } \\
\hline 29. & $\mathrm{NO}_{2}+\mathrm{e}=\mathrm{NO}_{2}^{-}$ & $1.8(13)$ & 0 & 0 & & & & [35] \\
\hline 30. & $\mathrm{NO}+\mathrm{e}+\mathrm{M}=\mathrm{NO}^{-}+\mathrm{M}$ & $3.6(17)$ & 0 & 0 & 0 & 0 & 0 & [35] \\
\hline 31. & $\mathrm{O}_{2}+\mathrm{e}+\mathrm{O}=\mathrm{O}_{2}^{-}+\mathrm{O}$ & $3.6(16)$ & 0 & 0 & & & & {$[35]$} \\
\hline 32. & $\mathrm{O}_{2}+\mathrm{e}+\mathrm{O}_{2}=\mathrm{O}_{2}^{-}+\mathrm{O}_{2}$ & $1.51(21)$ & -1 & 600 & $9.35(12)$ & 0.5 & 5590 & [35] \\
\hline 33. & $\mathrm{O}_{2}+\mathrm{e}+\mathrm{N}_{2}=\mathrm{O}_{2}^{-}+\mathrm{N}_{2}$ & $3.47(21)$ & -2 & 70 & $6.58(10)$ & 0.5 & 4990 & {$[35]$} \\
\hline 34. & $\mathrm{O}+\mathrm{e}+\mathrm{N}_{2}=\mathrm{O}^{-}+\mathrm{N}_{2}$ & $3.6(16)$ & 0 & 0 & & & & {$[55]$} \\
\hline 35. & $\mathrm{O}+\mathrm{e}+\mathrm{O}_{2}=\mathrm{O}^{-}+\mathrm{O}_{2}$ & $3.6(16)$ & 0 & 0 & & & & [35] \\
\hline
\end{tabular}

Nonresonance charge exchange

a) Positive ions

\begin{tabular}{|c|c|c|c|c|c|c|c|c|}
\hline 36. & $\mathrm{~N}_{2}^{+}+\mathrm{NO}_{2}=\mathrm{NO}_{2}^{+}+\mathrm{N}_{2}$ & $1.8(14)$ & 0 & 0 & & & & [42] \\
\hline 37. & $\mathrm{~N}^{+}+\mathrm{N}_{2}=\mathrm{N}_{2}^{+}+\mathrm{N}$ & $1(12)$ & 0.5 & 12199 & $1.37(17)$ & -0.83 & 3048 & [37] \\
\hline 38. & $\mathrm{~N}^{+}+\mathrm{NO}=\mathrm{N}+\mathrm{NO}^{+}$ & $5.4(14)$ & 0 & 0 & & & & [42] \\
\hline 39. & $\mathrm{~N}^{+}+\mathrm{O}=\mathrm{O}^{+}+\mathrm{N}$ & $3.39(5)$ & 1.58 & 0 & $4.65(8)$ & 0.96 & 12185 & {$[37]$} \\
\hline 40. & $\mathrm{NO}^{+}+\mathrm{N}_{2}=\mathrm{NO}+\mathrm{N}_{2}^{+}$ & $3.8(15)$ & 0 & 73231 & $1.47(17)$ & -0.72 & 765 & {$[37]$} \\
\hline 41. & $\mathrm{NO}^{+}+\mathrm{O}_{2}=\mathrm{NO}+\mathrm{O}_{2}^{+}$ & $2.4(13)$ & 0.41 & 32600 & $6.44(13)$ & 0.13 & 456 & {$[37]$} \\
\hline 42. & $\mathrm{NO}^{+}+\mathrm{O}=\mathrm{NO}+\mathrm{O}^{+}$ & $1.82(13)$ & 0 & 50129 & $1.21(13)$ & -0.06 & -460 & {$[37]$} \\
\hline 43. & $\mathrm{NO}_{2}^{+}+\mathrm{NO}=\mathrm{NO}^{+}+\mathrm{NO}_{2}$ & $1.74(14)$ & 0 & 0 & & & & {$[35,42]$} \\
\hline 44. & $\mathrm{O}_{2}^{+}+\mathrm{N}_{2}=\mathrm{O}_{2}+\mathrm{N}_{2}^{+}$ & $9.91(12)$ & 0 & 40700 & $1.44(14)$ & -0.44 & 379 & [37] \\
\hline 45. & $\mathrm{O}_{2}^{+}+\mathrm{N}=\mathrm{O}_{2}+\mathrm{N}^{+}$ & $8.71(13)$ & 0.14 & 28599 & $1.57(10)$ & 0.98 & -2030 & {$[37]$} \\
\hline 46. & $\mathrm{O}_{2}^{+}+\mathrm{NO}_{2}=\mathrm{NO}_{2}^{+}+\mathrm{O}_{2}$ & $5.28(14)$ & 0 & 0 & & & & {$[42]$} \\
\hline 47. & $\mathrm{O}_{2}^{+}+\mathrm{O}=\mathrm{O}_{2}+\mathrm{O}^{+}$ & $4(12)$ & -0.09 & 18000 & $9.84(11)$ & 0.13 & -424 & [37] \\
\hline 48. & $\mathrm{O}^{+}+\mathrm{N}_{2}=\mathrm{O}+\mathrm{N}_{2}^{+}$ & $9(11)$ & 0.36 & 22799 & $5.18(13)$ & -0.3 & 926 & {$[37]$} \\
\hline 49. & $\mathrm{O}^{+}+\mathrm{NO}_{2}=\mathrm{NO}_{2}^{+}+\mathrm{O}$ & $9.6(14)$ & 0 & 0 & & & & {$[35,42]$} \\
\hline 50. & $\mathrm{O}_{4}^{+}+\mathrm{NO}=\mathrm{NO}^{+}+\mathrm{O}_{2}+\mathrm{O}_{2}$ & $6(13)$ & 0 & 0 & 0 & 0 & 0 & {$[35]$} \\
\hline 51. & $\mathrm{H}_{2} \mathrm{O}^{+}+\mathrm{O}_{2}=\mathrm{O}_{2}^{+}+\mathrm{H}_{2} \mathrm{O}$ & $1.2(14)$ & 0 & 0 & & & & {$[21]$} \\
\hline 52. & $\mathrm{~N}_{2}^{+}+\mathrm{NH}_{3}=\mathrm{NH}_{3}^{+}+\mathrm{N}_{2}$ & $1.14(15)$ & 0 & 0 & 0 & 0 & 0 & [42] \\
\hline 53. & $\mathrm{~N}^{+}+\mathrm{NH}_{3}=\mathrm{NH}_{3}^{+}+\mathrm{N}$ & $1.44(15)$ & 0 & 0 & 0 & 0 & 0 & [42] \\
\hline 54. & $\mathrm{O}_{2}^{+}+\mathrm{NH}_{3}=\mathrm{NH}_{3}^{+}+\mathrm{O}_{2}$ & $6(14)$ & 0 & 0 & 0 & 0 & 0 & [42] \\
\hline 55. & $\mathrm{~N}_{2}^{+}+\mathrm{CO}=\mathrm{CO}^{+}+\mathrm{N}_{2}$ & $4.2(13)$ & 0 & 0 & & & & {$[21]$} \\
\hline 56. & $\mathrm{~N}_{2}^{+}+\mathrm{CO}_{2}=\mathrm{CO}_{2}^{+}+\mathrm{N}_{2}$ & $5.4(14)$ & 0 & 0 & & & & {$[21]$} \\
\hline 57. & $\mathrm{~N}^{+}+\mathrm{CO}=\mathrm{CO}^{+}+\mathrm{N}$ & $3(14)$ & 0 & 0 & & & & {$[21]$} \\
\hline 58. & $\mathrm{~N}^{+}+\mathrm{CO}_{2}=\mathrm{CO}_{2}^{+}+\mathrm{N}$ & $7.8(14)$ & 0 & 0 & & & & {$[21]$} \\
\hline 59. & $\mathrm{CO}^{+}+\mathrm{O}_{2}=\mathrm{O}_{2}^{+}+\mathrm{CO}$ & $1.2(14)$ & 0 & 0 & & & & {$[21]$} \\
\hline 60. & $\mathrm{CO}^{+}+\mathrm{CO}_{2}=\mathrm{CO}_{2}^{+}+\mathrm{CO}$ & $6.6(14)$ & 0 & 0 & & & & {$[21]$} \\
\hline 61. & $\mathrm{CO}_{2}^{+}+\mathrm{NO}=\mathrm{NO}^{+}+\mathrm{CO}_{2}$ & $7.2(13)$ & 0 & 0 & & & & {$[42]$} \\
\hline \multirow[t]{2}{*}{62.} & $\mathrm{CO}_{2}^{+}+\mathrm{O}_{2}=\mathrm{O}_{2}^{+}+\mathrm{CO}_{2}$ & $3.36(13)$ & 0 & 0 & & & & {$[42]$} \\
\hline & b) Negative ions & & & & & & & \\
\hline 63. & $\mathrm{NO}^{-}+\mathrm{NO}_{2}=\mathrm{NO}_{2}^{-}+\mathrm{NO}$ & $4.44(14)$ & 0 & 0 & 0 & 0 & 0 & {$[30]$} \\
\hline 64. & $\mathrm{NO}^{-}+\mathrm{O}_{2}=\mathrm{O}_{2}^{-}+\mathrm{NO}$ & $5.4(14)$ & 0 & 0 & 0 & 0 & 0 & {$[21]$} \\
\hline 65. & $\mathrm{NO}_{2}^{-}+\mathrm{NO}_{3}=\mathrm{NO}_{2}+\mathrm{NO}_{3}^{-}$ & $3(14)$ & 0 & 0 & & & & {$[35]$} \\
\hline 66. & $\mathrm{O}_{2}^{-}+\mathrm{NO}_{2}=\mathrm{NO}_{2}^{-}+\mathrm{O}_{2}$ & $4.2(14)$ & 0 & 0 & & & & {$[30,42]$} \\
\hline 67. & $\mathrm{O}_{2}^{-}+\mathrm{NO}_{3}=\mathrm{NO}_{3}^{-}+\mathrm{O}_{2}$ & $3(14)$ & 0 & 0 & & & & {$[35]$} \\
\hline
\end{tabular}




\begin{tabular}{|c|c|c|c|c|c|c|c|c|}
\hline \multirow[t]{2}{*}{ No. } & \multirow[t]{2}{*}{ Reaction } & \multicolumn{3}{|c|}{$k^{+}$} & \multicolumn{3}{|c|}{$k^{-}$} & \multirow[t]{2}{*}{ Ref. } \\
\hline & & A & $n$ & $E_{\mathrm{a}}$ & A & $n$ & $E_{\mathrm{a}}$ & \\
\hline 68. & $\mathrm{O}_{2}^{-}+\mathrm{O}=\mathrm{O}^{-}+\mathrm{O}_{2}$ & $1.98(14)$ & 0 & 0 & & & & [35] \\
\hline 70. & $\mathrm{O}^{-}+\mathrm{NO}_{2}=\mathrm{NO}_{2}^{-}+\mathrm{O}$ & $7.2(14)$ & 0 & 0 & 0 & 0 & 0 & {$[21,35]$} \\
\hline 71. & $\mathrm{O}^{-}+\mathrm{O}_{3}=\mathrm{O}_{3}^{-}+\mathrm{O}$ & $4.2(14)$ & 0 & 0 & 0 & 0 & 0 & [21] \\
\hline 72. & $\mathrm{O}^{-}+\mathrm{N}_{2} \mathrm{O}=\mathrm{N}_{2} \mathrm{O}^{-}+\mathrm{O}$ & $1.2(12)$ & 0 & 0 & 0 & 0 & 0 & [35] \\
\hline 75. & $\mathrm{H}^{-}+\mathrm{NO}_{2}=\mathrm{NO}_{2}^{-}+\mathrm{H}$ & $3(14)$ & 0 & 0 & & & & [21] \\
\hline 76. & $\mathrm{OH}^{-}+\mathrm{NO}_{2}=\mathrm{NO}_{2}^{-}+\mathrm{OH}$ & $6(14)$ & 0 & 0 & & & & [21] \\
\hline 77. & $\mathrm{OH}^{-}+\mathrm{O}_{3}=\mathrm{O}_{3}^{-}+\mathrm{OH}$ & $5.4(14)$ & 0 & 0 & 0 & 0 & 0 & {$[30]$} \\
\hline 78. & $\mathrm{O}_{2}^{-}+\mathrm{SO}_{2}=\mathrm{SO}_{2}^{-}+\mathrm{O}_{2}$ & $3.24(14)$ & 0 & 0 & 0 & 0 & 0 & [21] \\
\hline
\end{tabular}

Binary ion-molecular reactions

a) Positive ions

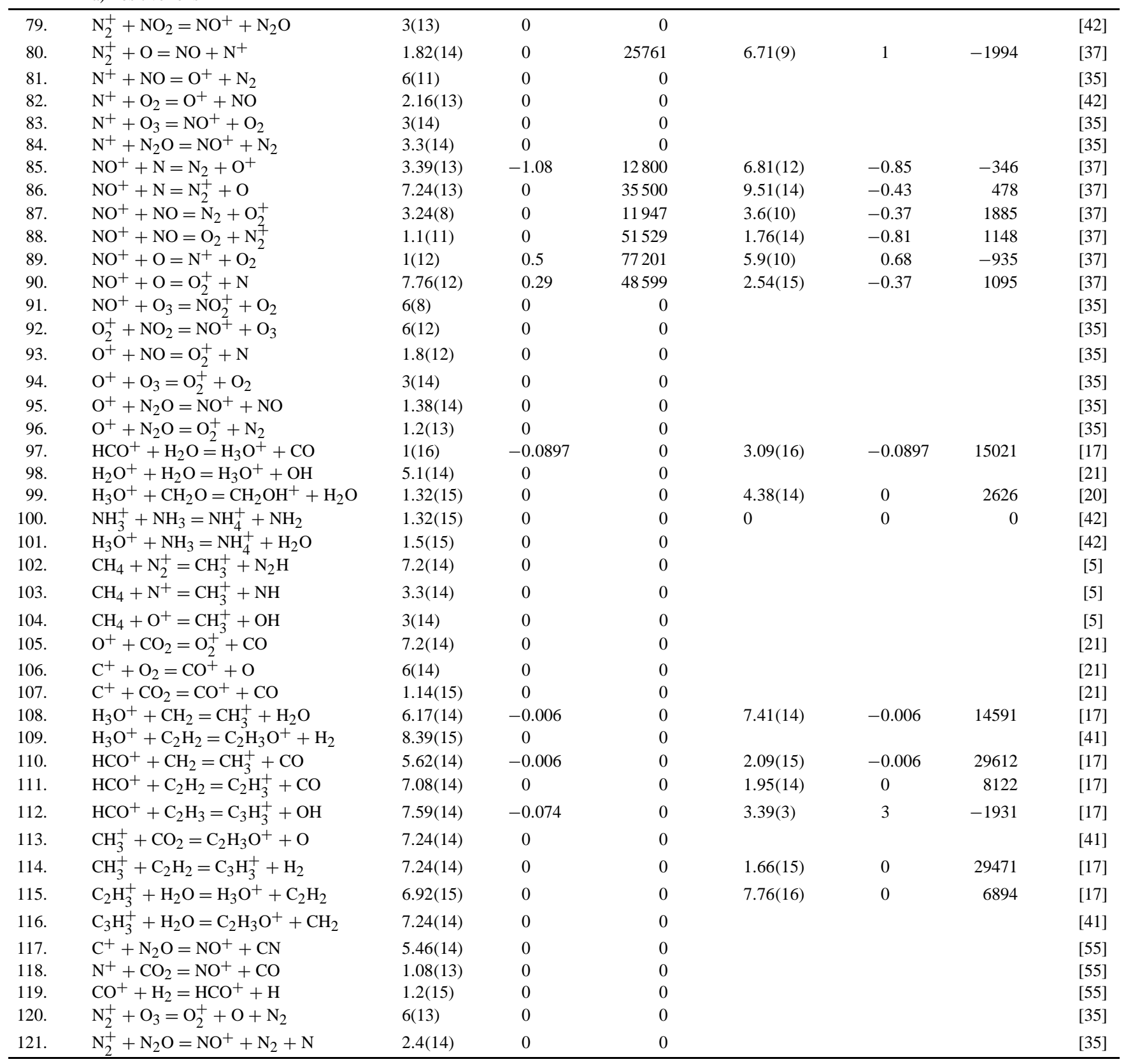




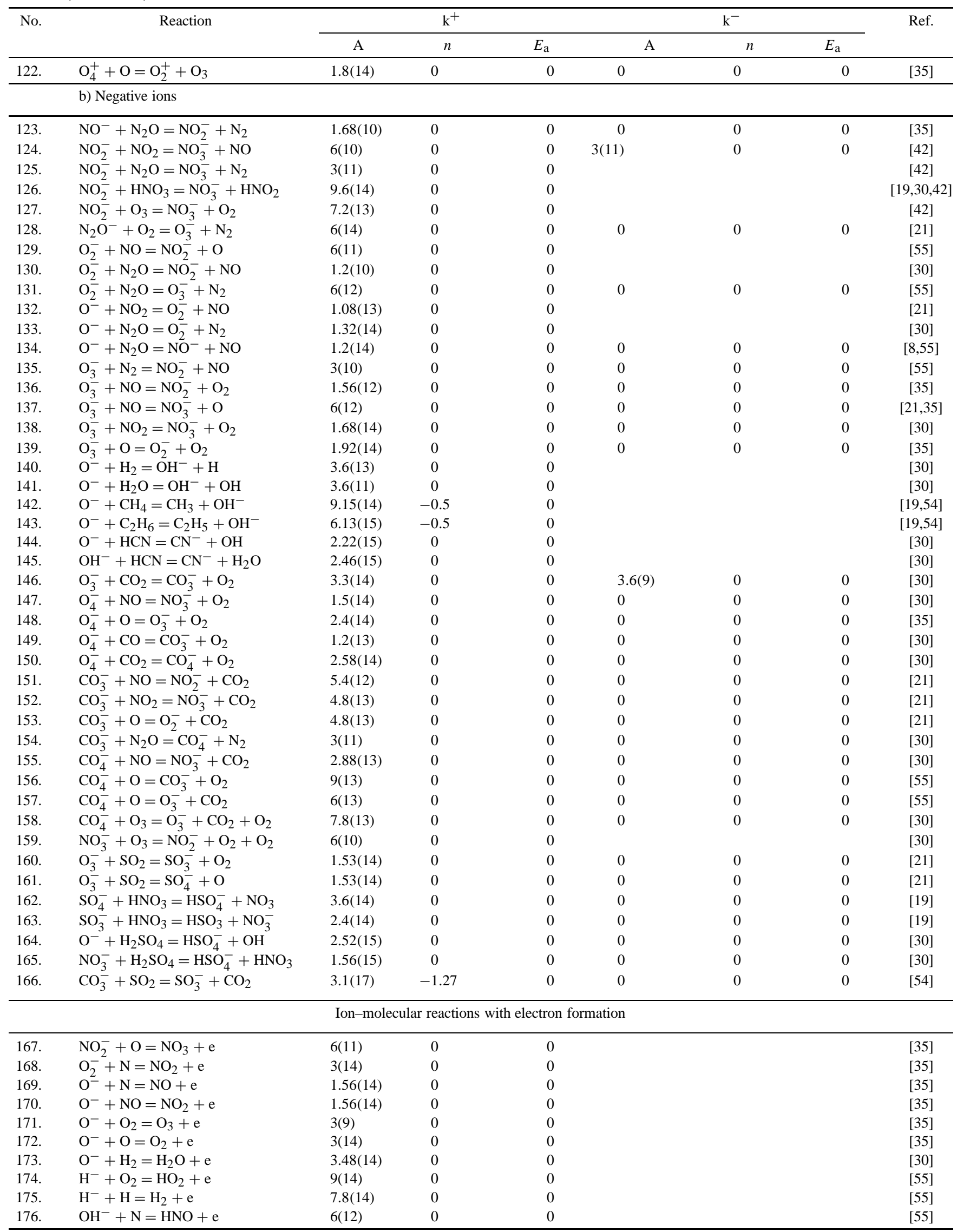




\begin{tabular}{|c|c|c|c|c|c|c|c|c|}
\hline \multirow[t]{2}{*}{ No. } & \multirow[t]{2}{*}{ Reaction } & \multicolumn{3}{|c|}{$k^{+}$} & \multicolumn{3}{|c|}{$k^{-}$} & \multirow[t]{2}{*}{ Ref. } \\
\hline & & A & $n$ & $E_{\mathrm{a}}$ & A & $n$ & $E_{\mathrm{a}}$ & \\
\hline 177. & $\mathrm{OH}^{-}+\mathrm{O}=\mathrm{HO}_{2}+\mathrm{e}$ & $1.2(14)$ & 0 & 0 & & & & [55] \\
\hline 178. & $\mathrm{OH}^{-}+\mathrm{H}=\mathrm{H}_{2} \mathrm{O}+\mathrm{e}$ & $6(14)$ & 0 & 0 & & & & [55] \\
\hline 180. & $\mathrm{O}^{-}+\mathrm{CO}=\mathrm{CO}_{2}+\mathrm{e}$ & $3.3(14)$ & 0 & 0 & & & & [30] \\
\hline 181. & $\mathrm{O}_{2}^{-}+\mathrm{N}=\mathrm{NO}+\mathrm{O}+\mathrm{e}$ & $2.4(14)$ & 0 & 0 & & & & [55] \\
\hline 182. & $\mathrm{O}_{3}^{-}+\mathrm{O}=\mathrm{O}_{2}+\mathrm{O}_{2}+\mathrm{e}$ & $1.8(14)$ & 0 & 0 & 0 & 0 & 0 & [35] \\
\hline 185. & $\mathrm{NO}^{-}+\mathrm{NO}=\mathrm{e}+\mathrm{NO}+\mathrm{NO}$ & $3(12)$ & 0 & 0 & 0 & 0 & 0 & [30] \\
\hline 186. & $\mathrm{NO}^{-}+\mathrm{N}_{2} \mathrm{O}=\mathrm{e}+\mathrm{NO}+\mathrm{N}_{2} \mathrm{O}$ & $3.06(12)$ & 0 & 0 & 0 & 0 & 0 & [30] \\
\hline 187. & $\mathrm{O}_{3}^{-}+\mathrm{N}_{2} \mathrm{O}=\mathrm{e}+\mathrm{N}_{2}+\mathrm{O}_{2}+\mathrm{O}_{2}$ & $1.2(10)$ & 0 & 0 & 0 & 0 & 0 & [30] \\
\hline
\end{tabular}

Ternary recombination of ion and neutral

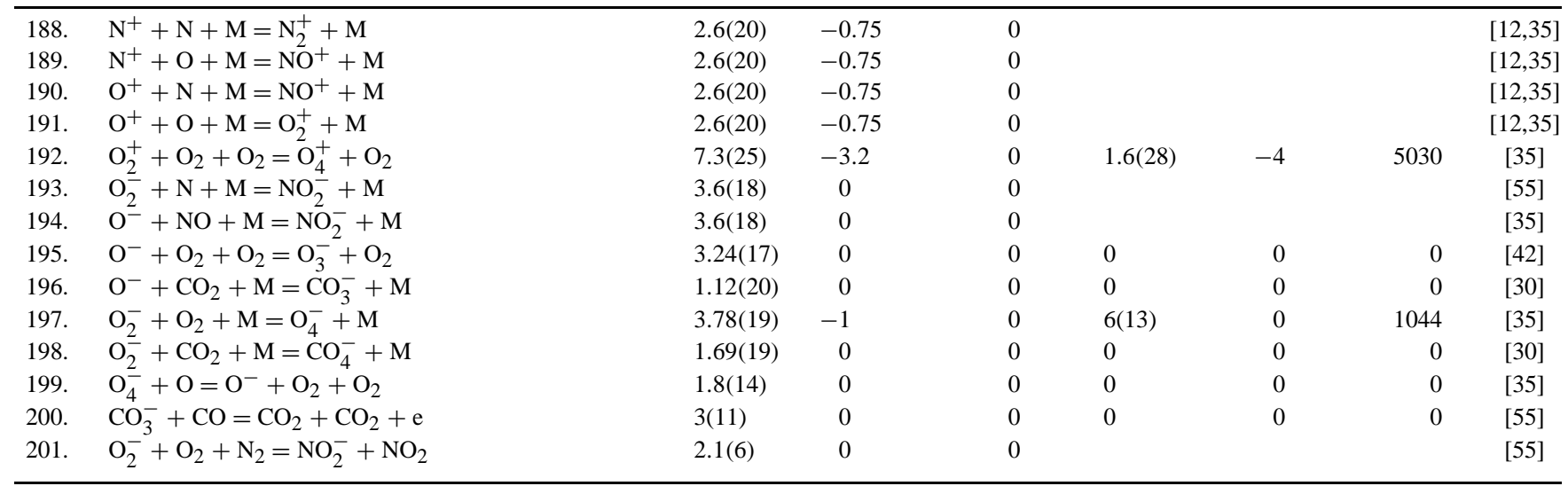

\begin{tabular}{|c|c|c|c|c|c|c|c|c|}
\hline \multicolumn{9}{|c|}{ Dissociative recombination } \\
\hline 202. & $\mathrm{NO}_{2}^{+}+\mathrm{e}=\mathrm{NO}+\mathrm{O}$ & $2.08(18)$ & -0.5 & 0 & & & & [35] \\
\hline 203. & $\mathrm{H}_{3} \mathrm{O}^{+}+\mathrm{e}=\mathrm{H}_{2} \mathrm{O}+\mathrm{H}$ & $2.29(18)$ & -0.5 & 0 & $7.41(-7)$ & 3 & 40453 & {$[17]$} \\
\hline 204. & $\mathrm{CO}_{2}^{+}+\mathrm{e}=\mathrm{CO}+\mathrm{O}$ & $3.6(16)$ & 0 & 0 & & & & [55] \\
\hline 205. & $\mathrm{CH}_{3}^{+}+\mathrm{e}=\mathrm{CH}_{2}+\mathrm{H}$ & $2.29(18)$ & -0.5 & 0 & $3.39(-2)$ & 3 & 43779 & [17] \\
\hline 206. & $\mathrm{C}_{2} \mathrm{H}_{3}^{+}+\mathrm{e}=\mathrm{C}_{2} \mathrm{H}_{2}+\mathrm{H}$ & $2.29(18)$ & -0.5 & 0 & $1.02(-7)$ & 3 & 39872 & {$[17]$} \\
\hline 207. & $\mathrm{C}_{2} \mathrm{H}_{3} \mathrm{O}^{+}+\mathrm{e}=\mathrm{CH}_{2} \mathrm{CO}+\mathrm{H}$ & $2.29(18)$ & -0.5 & 0 & 0 & 0 & 0 & {$[41]$} \\
\hline \multicolumn{9}{|c|}{ Ion-electron recombination } \\
\hline 210. & $\mathrm{NO}_{2}^{+}+\mathrm{e}=\mathrm{NO}_{2}$ & $1.2(19)$ & 0 & 0 & & & & {$[42]$} \\
\hline 211. & $\mathrm{O}^{+2}+\mathrm{e}+\mathrm{O}_{2}=\mathrm{O}+\mathrm{O}_{2}$ & $1(30)$ & -3.5 & 0 & & & & {$[12,35]$} \\
\hline & $\mathrm{O}^{+}+\mathrm{e}+\mathrm{N}_{2}=\mathrm{O}+\mathrm{N}_{2}$ & $1(30)$ & -3.5 & 0 & & & & {$[12,35]$} \\
\hline
\end{tabular}

Binary ion-ion recombination

\begin{tabular}{|c|c|c|c|c|c|c|c|c|}
\hline 216. & $\begin{array}{l}\mathrm{A}^{-}+\mathrm{B}^{+}=\mathrm{A}+\mathrm{B} \\
\mathrm{A}=\mathrm{O}_{2}, \mathrm{O}, \mathrm{O}_{3}, \mathrm{NO}, \mathrm{NO}_{2}, \mathrm{NO}_{3}, \mathrm{~N}_{2} \mathrm{O}, \mathrm{SO}_{2}, \mathrm{SO}_{3}, \mathrm{CN} \\
\mathrm{B}=\mathrm{N}_{2}, \mathrm{O}_{2}, \mathrm{~N}, \mathrm{O}, \mathrm{NO}, \mathrm{NO}_{2}, \mathrm{CO}, \mathrm{CO}_{2}, \mathrm{NH}_{3}, \mathrm{C}_{2} \mathrm{H}_{3} \mathrm{O}\end{array}$ & $2.09(18)$ & -0.5 & 0 & & & & [35] \\
\hline 217. & $\begin{array}{l}\mathrm{A}^{-}+(\mathrm{BC})^{+}=\mathrm{A}+\mathrm{B}+\mathrm{C} \\
\mathrm{A}=\mathrm{O}_{2}, \mathrm{O}, \mathrm{O}_{3}, \mathrm{NO}, \mathrm{NO}_{2}, \mathrm{NO}_{3}, \mathrm{~N}_{2} \mathrm{O}, \mathrm{SO}_{2}, \mathrm{SO}_{3}, \mathrm{CN} \\
(\mathrm{BC})=\mathrm{N}_{2}, \mathrm{O}_{2}, \mathrm{NO}, \mathrm{NO}_{2}, \mathrm{O}_{4}, \mathrm{C}_{2} \mathrm{H}_{3} \mathrm{O}\end{array}$ & $6.02(16)$ & 0 & 0 & & & & [35] \\
\hline 218. & $\begin{array}{l}(\mathrm{AB})^{-}+\mathrm{C}^{+}=\mathrm{A}+\mathrm{B}+\mathrm{C} \\
(\mathrm{AB})=\mathrm{O}_{4} \\
\mathrm{C}=\mathrm{N}_{2}, \mathrm{O}_{2}, \mathrm{~N}, \mathrm{O}, \mathrm{NO}, \mathrm{NO}_{2}\end{array}$ & $6.02(16)$ & 0 & 0 & & & & [35] \\
\hline 220. & $\mathrm{O}_{4}^{-}+\mathrm{O}_{4}^{+}=\mathrm{O}_{2}+\mathrm{O}_{2}+\mathrm{O}_{2}+\mathrm{O}_{2}$ & $6.02(16)$ & 0 & 0 & 0 & 0 & 0 & [35] \\
\hline
\end{tabular}




\begin{tabular}{|c|c|c|c|c|c|c|c|c|}
\hline \multirow[t]{2}{*}{ No. } & \multirow[t]{2}{*}{ Reaction } & \multicolumn{3}{|c|}{$k^{+}$} & \multicolumn{3}{|c|}{$k^{-}$} & \multirow[t]{2}{*}{ Ref. } \\
\hline & & A & $n$ & $E_{\mathrm{a}}$ & A & $n$ & $E_{\mathrm{a}}$ & \\
\hline \multicolumn{9}{|c|}{ Ternary ion-ion recombination } \\
\hline
\end{tabular}

\section{References}

[1] F. Arnold, J. Scheid, T. Stilp, H. Schlager, M.E. Reinhardt, Measurements of jet aircraft emissions at cruise altitude, 1, The odd-nitrogen gases $\mathrm{NO}, \mathrm{NO}_{2}, \mathrm{HNO}_{2}$, and $\mathrm{HNO}_{3}$, Geophys. Res. Lett. 19 (1992) 2421-2424.

[2] F. Arnold, T. Stilp, R. Busen, U. Schumann, Jet engine exhaust chemiion measurements: Implications for gaseous $\mathrm{SO}_{3}$ and $\mathrm{H}_{2} \mathrm{SO}_{4}$, Atmos. Env. 32 (1998) 3073-3077.

[3] F. Arnold, K.H. Wohlfrom, M.W. Klemm, J. Schneider, K. Gollinger, U. Schumann, R. Busen, First gaseous ion composition measurements in the exhaust plume of jet aircraft in flight: Implications for gaseous sulfuric acid, aerosols, and chemiions, Geophys. Res. Lett. 25 (1998) 2137-2140.

[4] F. Arnold, A. Kiendler, V. Wiedemer, S. Aberle, T. Stilp, R. Busen, Chemiion concentration measurements in jet engine exhaust at the ground: Implications for ion chemistry and aerosol formation in the wake of a jet aircraft, Geophys. Res. Lett. 27 (2000) 1723-1726.

[5] S.T. Arnold, R.A. Morris, A.A. Viggiano, Reactions of O- with various alkanes: competition between hydrogen abstraction and reactive detachment, J. Phys. Chem. A 102 (1997) 1345-1348.

[6] S. Böckle, S. Einecke, F. Hildenbrand, C. Orlemann, A. Schulz, J. Wolfrum, V. Sick, Laser-spectroscopic investigation of $\mathrm{OH}$-radical concentrations in the exhaust plane of jet engines, Geophys. Res. Lett. 26 (1999) 1849-1852.

[7] G.P. Brasseur, R.A. Cox, D. Hauglustaine, I. Isaksen, J. Lelieveld, D.H. Lister, R. Sausen, U. Schumann, A. Wahner, P. Wiesen, European scientific assessment of the atmospheric effects of aircraft emissions, Atmos. Env. 32 (1998) 2329-2418.

[8] R.C. Brown, R.C. Miake-Lye, C.E. Kolb, A.A. Sorokin, Ya.Y. Buriko, Aircraft exhaust sulfur emissions, Geophys. Res. Lett. 23 (1996) 3603-3606.

[9] R.C. Brown, R.C. Miake-Lye, M.R. Anderson, C.E. Kolb, Effect of aircraft exhaust sulfur emission on near field plume aerosols, Geophys. Res. Lett. 23 (1996) 3607-3610.

[10] H.F. Calcote, Ionic mechanisms of soot formation, in: J. Lahaye, G. Prado (Eds.), Soot in combustion systems and its toxic properties, NATO Conference series. Series VI: Materials Science, Plenum Press, New York, 1981, pp. 197-215.

[11] H.F. Calcote, D.G. Keil, The role of ions in soot formation, Pure Appl. Chem. 62 (1990) 815-824.

[12] G.G. Chernyi, S.A. Losev (Eds.), Physical and chemical processes in gas dynamics. V. 1. Cross sections and rate constants for physical and chemical processes (2002), in press.

[13] J. Curtius, B. Sierau, F. Arnold, R. Baumann, R. Busen, P. Schulte, U. Schumann, First sulfuric acid detection in the exhaust plume of a jet aircraft in flight, Geophys. Res. Lett. 25 (1998) 923-926.

[14] J. Curtius, F. Arnold, P. Schulte, Sulfuric acid measurements in the exhaust plume of a jet aircraft in flight: Implications for the sulfuric acid formation efficiency, Geophys. Res. Lett. (2002), in press.
[15] N.G. Dautov, A.M. Starik, On the problem of choosing a kinetic scheme for the homogeneous reaction of methane with air, Kinetics and Catalysis 38 (1997) 185-208.

[16] W.B. DeMore, S.P. Sander, D.M. Golden, R.F. Hampson, M.J. Kurylo, C.J. Howard, A.R. Ravishankara, C.E. Kolb, M.J. Molina, Chemical kinetics and photochemical data for use in stratospheric modeling. Evaluation 11, JPL Publication 94-26. Jet propulsion laboratory, Pasadena, California (1994).

[17] A.N. Eraslan, R.C. Brown, Chemiionization and ion-molecule reactions in fuel-rich acetylene flames, Combust. Flame 74 (1988) 19-37.

[18] D.W. Fahey et al., Emission measurements of the Concorde supersonic aircraft in the lower stratosphere, Science 270 (1995) 70-74.

[19] F.C. Fehsenfeld, C.J. Howard, A.L. Schmeltekopp, Gas phase ion chemistry of $\mathrm{HNO}_{3}$, J. Chem. Phys. 63 (1975) 2835-2841.

[20] F.C. Fehsenfeld, I. Dotan, D.J. Albritton, C.J. Howard, E.E. Ferguson, Stratospheric positive ion chemistry of formaldehyde and methanol, J. Geophys. Res. 83 (1978) 1333-1336.

[21] E.E. Ferguson, Negative ion-molecular reactions, Canadian J. Chem. 47 (1969) 1815-1820.

[22] A.B. Fialkov, Investigations on ions in flames, Progr. Energy Comb. Sci. 23 (1997) 399-528.

[23] A. Frenzel, F. Arnold, Sulfuric acid cluster ion formation by jet engines: Implications for sulfuric acid formation and nucleation. DLRMitt. 94-06, Deutsches Zentrum für Luft- und Raumfahrt, Köln, Germany (1994) 106-112.

[24] J. Goodings, K.D. Bohme, T.M. Sugden, Sixteenth Symposium (International) on Combustion, The Combustion Institute, Pittsburgh, 1977, pp. 891-902.

[25] J.F. Griffits, J.A. Barnard, Flame and Combustion, Chapman and Hall, London, 1995.

[26] R.W.F. Gross, J.F. Bott (Eds.), Handbook of Chemical Lasers. A Wiley-Interscience Publication, John Wiley and Sons, New York, 1976.

[27] J.E. Penner, D.H. Lister, D.J. Griggs, D.J. Dokken, M. McFarland (Eds.), Aviation and the Global Atmosphere, A Special Report of IPCC (Intergovernmental Panel on Climate Change), Cambridge Univ. Press, Cambridge, UK, 1999.

[28] B. Kärcher, F. Yu, F.P. Schröder, R.P. Turco, Ultrafine aerosol particles in aircraft plumes: Analysis of growth mechanisms, Geophys. Res. Lett. 25 (1998) 2793-2796.

[29] B. Kärcher, R.P. Turco, F. Yu, M.Y. Danilin, D.K. Weisenstein, R.C. Miake-Lye, R. Busen, On the unification of aircraft ultrafine particle emission data, J. Geophys. Res. 105 (2000) 29379-29386.

[30] H. Kawamoto, T. Ogawa, Steady state model of negative ions in the lower atmosphere, Planetary and Space Science 32 (1984) 1223-1233.

[31] D.G. Keil, R.J. Gill, D.B. Olson, F. Calcote, Ion concentrations in premixed acetylene-oxygen flames near the soot threshold, in: T.M. Sloane (Ed.), The Chemistry of Combustion Processes, ACS Symposium Series, Vol. 249, American Chemical Society, Washington, 1984, pp. 33-47. 
[32] A. Kiendler, S. Aberle, F. Arnold, Negative chemiions formed in jet fuel combustion: New insights from jet engine and laboratory measurements using a quadrupole ion trap mass spectrometer apparatus, Atmos. Env. 34 (2000) 2623-2632.

[33] A. Kiendler, S. Aberle, F. Arnold, Positive ion chemistry in the exhaust plumes of an aircraft jet engine and a burner: Investigations with a quadrupole ion trap mass spectrometer, Atmos. Env. 34 (2000) 47874793.

[34] O. Knab, T.A. Gogel, H.-H. Frühauf, E.W. Messerschmid CVCVmodel validation by means of radiative heating calculations, AIAA 95-0623 (1995).

[35] I.A. Kossyi, Yu.A. Kostinsky, A.A. Matveyev, V.P. Silakov, Kinetic scheme of the non-equilibrium discharge in nitrogen-oxygen mixtures, Plasma Sources Sci. Techn. 1 (1992) 207-220.

[36] S.P. Lukachko, I.A. Waitz, R.C. Miake-Lye, R.C. Brown, M.R. Anderson, Production of sulfate aerosol precursors in the turbine and exhaust nozzle of an aircraft engine, J. Geophys. Res. 103 (1998) 16159-16174.

[37] V.N. Makarov, Construction of the optimal kinetic models in physicalchemical gas dynamics, Dissertation of Doctor of Science in Physics and Mathematics, Moscow State University (1996).

[38] R.C. Miake-Lye, B.E. Anderson, W.R. Cofer, H.A. Wallio, G.D. Nowicki, J.O. Ballenthin, D.E. Hunton, W.B. Knighton, T.M. Miller, J.V. Seeley, A.A. Viggiano, $\mathrm{SO}_{x}$ oxidation and volatile aerosol in aircraft exhaust plumes depend on fuel sulfur content, Geophys. Res. Lett. 25 (1998) 1677-1680.

[39] R.C. Miake-Lye, A.T. Chobot, S.P. Lukachko, R.C. Brown, J. Zhang, I.A. Waitz, Simulation of post-combustion chemical evolution in gas turbine engines, in: U. Schumann, G.T. Amanatidis (Eds.), Aviation, Aerosols, Contrails and Cirrus Clouds, 2001, pp. 95-98. EUR 19428, European Commission, Brussels.

[40] C. Park, Nonequilibrium Hypersonic Aerothermodynamics, Wiley, New York, 1990.

[41] T. Pedersen, R.C. Brown, Simulation of electric field effects in premixed methane flames, Combust. Flame 94 (1993) 433-448.

[42] J.C. Person, D.O. Ham, Removal of $\mathrm{SO}_{2}$ and $\mathrm{NO}_{x}$ from stack gases by electron beam irradiation, Radiative Physical Chemistry 31 (1988) $1-8$.

[43] J. Peters, G. Mahnen, Fourteenth Symposium (International) on Combustion, The Combustion Institute, Pittsburgh, 1972, 133-146.

[44] B.V. Potapkin, V.D. Rusanov, M.I. Strelkova, A.A. Fridmann, Investigation of kinetics and energetics of dissociation processes of $\mathrm{H}_{2} \mathrm{~S}$ mixed with $\mathrm{CO}_{2}$ in thermal plasma, High Energy Chemistry 23 (1992) 63-68.

[45] T. Reiner, F. Arnold, Laboratory flow reactor measurements of the reaction $\mathrm{SO}_{3}+\mathrm{H}_{2} \mathrm{O}+\mathrm{M} \rightarrow \mathrm{H}_{2} \mathrm{SO}_{4}+\mathrm{M}$ : Implications for gaseous $\mathrm{H}_{2} \mathrm{SO}_{4}$ and aerosol formation in the plume of jet aircraft, Geophys. Res. Lett. 20 (1993) 2659-2662.

[46] A.M. Savel'ev, A.M. Starik, N.S. Titova, Investigation of the dynamics of formation of environmentally harmful gases in elements of gas turbine engine, High Temperature 37 (1999) 470-478.

[47] O.P. Schatalov, in: G.G. Cherniy, V.A. Levin (Eds.), Nonequilibrium Gas Flow with Physico-Chemical Transformation, Moscow State University, 1980, pp. 39-62.
[48] P. Schulte, H. Schlager, H. Ziereis, U. Schumann, S.L. Baughcum, F. Deidewig, $\mathrm{NO}_{x}$ emission indices of subsonic long-range jet aircraft at cruise altitude: In situ measurements and predictions, J. Geophys. Res. 102 (1997) 21431-21442.

[49] U. Schumann (Ed.), AERONOX - The impact of $\mathrm{NO}_{x}$ emissions from aircraft upon the atmosphere at flight altitudes $8-15 \mathrm{~km}$. EUR 16209 , 1995, 471 pp. Office for Publications of the European Community, Brussels.

[50] U. Schumann, J. Ström, R. Busen, R. Baumann, K. Gierens, M. Krautstrunk, F.P. Schröder, J. Stingl, In situ observations of particles in jet aircraft exhausts and contrails for different sulfur containing fuels, J. Geophys. Res. 101 (1996) 6853-6899.

[51] U. Schumann, H. Schlager, F. Arnold, R. Baumann, P. Haschberger, O. Klemm, Dilution of aircraft exhaust plumes at cruise altitudes, Atmos. Env. 32 (1998) 3097-3103.

[52] U. Schumann, H. Schlager, F. Arnold, J. Ovarlez, H. Kelder, Ø. Hov, G. Hayman, I.S.A. Isaksen, J. Staehelin, P.D. Whitefield, Pollution from aircraft emissions in the North Atlantic flight corridor: Overview on the POLINAT projects, J. Geophys. Res. 105 (2000) 3605-3631.

[53] U. Schumann, F. Arnold, R. Busen, J. Curtius, B. Kärcher, A. Kiendler, A. Petzold, H. Schlager, F. Schröder, K.-H. Wohlfrom, Influence of fuel sulfur on the composition of aircraft exhaust plumes: The experiments SULFUR 1-7, J. Geophys. Res. 107 (2002), in press.

[54] J.V. Seeley, R.A. Morris, A.A. Viggiano, Rate constants for the reactions of $\mathrm{CO}_{3}^{-}\left(\mathrm{H}_{2} \mathrm{O}\right)_{n=0-5}+\mathrm{SO}_{2}$ : implications for CIMS detection of $\mathrm{SO}_{2}$, Geophys. Res. Lett. 24 (1997) 1379-1382.

[55] K. Smith, R.M. Thompson, Computer Modeling of Gas Lasers, Plenum Press, New York, 1978.

[56] A.M. Starik, N.S. Titova, L.S. Yanovskii, Analysis of the singularities of the kinetics of combustion of the products of thermal destruction of n-octane mixed with air, High Temperature 37 (1999) 270-281.

[57] A.M. Starik, N.S. Titova, L.S. Yanovskii, Kinetics of the oxidation of the products from the thermal destruction of $\mathrm{C}_{3} \mathrm{H}_{8}$ and $n-\mathrm{C}_{4} \mathrm{H}_{10}$ in the mixtures with air, Kinetics and Catalysis 40 (1999) 7-22.

[58] H.G. Tremmel, U. Schumann, Model simulations of fuel sulfur conversion efficiencies in an aircraft engine: Dependence on reaction rate constants and initial species mixing ratios, Aerosp. Sci. Technol. 3 (1999) 417-430.

[59] H.G. Tremmel, H. Schlager, P. Konopka, P. Schulte, F. Arnold, M. Klemm, B. Droste-Franke, Observations and model calculations of jet aircraft exhaust products at cruise altitude and inferred initial $\mathrm{OH}$ emissions, J. Geophys. Res. 103 (1998) 10803-10816.

[60] F. Yin, D. Grosjean, J.H. Seinfeld, Analysis of atmospheric photooxidation mechanism for organosulfur compounds, J. Geophys. Res. 91 (1986) 14417-14438.

[61] F. Yu, R.P. Turco, The role of ions in the formation and evolution of particles in aircraft plumes, Geophys. Res. Lett. 24 (1997) 1927-1930.

[62] F. Yu, R.P. Turco, B. Kärcher, F.P. Schröder, On the mechanisms controlling the formation and properties of volatile particles in aircraft wakes, Geophys. Res. Lett. 25 (1998) 3839-3842. 